Z Badań nad Książką i Księgozbiorami Historycznymi 2020, t. 14, z. 2

The Studies into the History of the Book and Book Collections 2020, vol. 14, no. 2

www.bookhistory.uw.edu.pl

Krzysztof Dawid Majus

niezależny badacz

Lod, Izrael

davmajus@gmail.com

(iD) 0000-0003-3588-0995

\title{
Drukarze i wydawcy hebrajskich i żydowskich druków w Przemyślu
}

\section{Printers and publishers of the Hebrew and Yiddish prints in Przemyśl}

Abstract: This article was written during the work on a monograph of Hebrew and Yiddish publications printed or published in Przemyśl. It is based on materials collected for the chapter dedicated to biographies of printers and publishers of such publications who were active in Przemyśl from the year 1869 - the beginning of Hebrew and Yiddish printing in Przemyśl - until the outbreak of the World War II. The article divides into two main parts. The first is dedicated to biographies and achievements of the printers Dov Ber Lorje and the Knoller and Żupnik families; the second focuses on the Amkraut and Freund publishing families.

Key words: Przemyśl 1869-1939 - Jewish printers - Jewish publishers - Hebrew prints -Yiddish prints.

Słowa kluczowe: Przemyśl 1869-1939 - drukarze żydowscy - wydawcy żydowscy - druki hebrajskie - druki w jidysz.

„Z Badań nad Książką i Księgozbiorami Historycznymi” - Udział zagranicznych recenzentów w ocenie publikacji; Stworzenie anglojęzycznej wersji wydawniczej publikacji; Digitalizacja tomów archiwalnych rocznika w celu zapewnienia otwartego dostępu do nich przez Internet oraz wdrożenie i utrzymanie cyfrowej platformy redakcyjnej - zadanie finansowane w ramach umowy nr 653/P-DUN/2019 ze środków Ministra Nauki i Szkolnictwa Wyższego przeznaczonych na działalność upowszechniającą naukę. 
W roku 2019 minęło 150 lat od wydania w Przemyślu pierwszej księgi w języku hebrajskim. Swoistym paradoksem jest fakt, że Przemyśl - miasto słusznie szczycące się pierwszą wzmianką o osiedlaniu się Żydów na ziemiach polskich już w XI w., doczekało się pierwszej drukarni ksiąg hebrajskich dopiero w końcu siódmej dekady XIX w., podczas gdy drukarnie takie działały już od kilku bądź nawet kilkunastu dekad w tak nieodległych miastach jak Żółkiew (od roku 1691), Turka (od 1752), Lwów (od 1782) czy Hrubieszów (od 1816). Być może pewnym wyjaśnieniem tego paradoksu jest fakt, że drukarstwo w ogóle pojawiło się w Przemyślu dość późno, bo dopiero w latach 50. XVIII w. (rok 1754) ${ }^{1}$. Niniejszy artykuł poświęcony jest żydowskim drukarzom i wydawcom z Przemyśla a nie samym drukarniom, gdyż ich dzieje i opis znaleźć można w pracy Anny Siciak, Dzieje ksiązki w Przemyślu w okresie autonomii Galicji (1867-1914), wydanej w Przemyślu w 2012 r.

\section{Drukarze}

\section{Dow Ber Lorje}

Niekwestionowanym prekursorem hebrajskiego drukarstwa w Przemyślu był Dow Ber Lorje, występujący często w dokumentach i publikacjach tylko pod zdrobniałymi formami swego drugiego imienia: Berl lub Berysz (Berisch) ${ }^{2}$. Pochodził ze znanej rodziny Lurie (zapisywanej także Lurye, Luriye, Loria, Lourié itp.), która wydała wielu znamienitych rabinów i uczonych w piśmie, posiadającej jedno z najstarszych na świecie udokumentowanych drzew genealogicznych, sięgające X w. p.n.e., aż do Dawida, króla Izraela, i dalej. Samo nazwisko wywodzone jest od miejscowości Loria w prowincji Treviso we Włoszech bądź od Loire-sur-Rhône w departamencie Rhône we Francji ${ }^{3}$.

D.B. Lorje urodził się w Brodach 1 VIII 1831 r. Jego dziadkiem był rabin Zborowa o tych samych imionach (ur. 1787, zm. 1829 we Lwowie), który poślubił Deborę (ur. 1783, zm. 1848 we Lwowie) ${ }^{4}$. Jednym z ich dzieci i ojcem

\footnotetext{
A. Jagusztyn, Drukarstwo regionu przemyskiego w okresie II Rzeczypospolitej, „Przemyskie Zapiski Historyczne" 1980, t. 2, s. 134.

2 „Dow” to w języku hebrajskim niedźwiedź, podobnie jak „Ber” w jidysz. Zgodnie z dość powszechnym zwyczajem nadawano często dwa tożsame znaczeniowo imiona - hebrajskie, jako imię ,święte”, używane tylko przy ceremoniach religijnych, i imię na co dzień w jidysz, tzw. kinuj (przydomek).

3 N. Rosenstein, R. Lurie, The Lurie Legacy. The House of Davidic Royal Descent, Bergenfield (N.J.) 2004.

${ }_{4}$ Ch. Vital, Limudej acilut [Nauka szlachetności], Lwów 1850, strona tytułowa; Portal Gesher Galicia, The Bridge to Galicia: ID lviv_deaths_revised-16021, Berl Lorje - akt zgonu, [online] https://search.geshergalicia.org [dostęp 29.03.2020].
} 
Dowa Bera był Tobiasz Wolf Zeew Lorje (ur. 1809 we Lwowie, zm. 1836 we Lwowie), który poślubił Rebekę (Rywkę) z domu Sapir5. W roku 1860 Dow Ber poślubił we Lwowie młodszą od siebie o dziewięć lat Itę (Jütte) Schorr, córkę Meszulama Abla i Liby Perl z domu Brück ${ }^{6}$.

D.B. Lorje już od młodych lat zajmował się we Lwowie działalnością wydawniczą. Pierwsza znana wzmianka o nim stwierdza, iż w roku 1850, mając zaledwie 19 lat, rozpoczął kierowanie działem hebrajskich ksiąg w niedawno powstałej drukarni Michała Franciszka Poremby ${ }^{7}$. Współpraca z Porembą trwała do roku 1858 i zaowocowała wydaniem licznych publikacji w języku hebrajskim i w jidysz. Poza księgami religijnymi Lorje drukował wtedy także propagujący idee oświeceniowe miesięcznik w języku hebrajskim „Jeszurun” (lipiec-grudzień 1857$)^{8}$. Już wówczas rozpoczął kontynuowaną potem w różnych formach współpracę z Cwi Hirszem Sperlingiem (synem Zeewa Wolfa z Dynowa), który objął po nim (do roku 1860) kierownictwo działu ksiąg hebrajskich w drukarni Poremby i był później wydawcą niektórych drukowanych przez Lorję ksiąg9 .

Mając już wyrobioną pozycję na lwowskim rynku wydawniczym i drukarskim D.B. Lorje założył w końcu roku 1858 drukarnię w szczycącej się wieloletnimi tradycjami hebrajskiego drukarstwa Żółkwi. Uczynił to wspólnie z innym znanym lwowskim drukarzem Lejbem Madpisem (Madfis, Madfes, Matfes, Matfus ${ }^{10}$. Przedsięwzięcie to utrzymało się jednak tylko niecałe dwa lata i w roku 1860 obydwaj drukarze powrócili do Lwowa ${ }^{11}$.

W dniu 18 X 1860 r. D.B. Lorje i Cwi Hirsz Sperling powołali we Lwowie do życia własną drukarnię. Poza hebrajskimi księgami Lorje i Sperling drukowali od 2 VIII 1861 r. do 3 I 1862 r. (42 numery) ukazujący się dwa razy w tygodniu lwowski periodyk w jidysz „Der Galicisze Bote: Cajtung

5 Gesher Galicia: ID lviv_births_revised-2577, Wolf Tobias Lorje - akt urodzenia; ID brody-births-11730, Ber Lerie - akt urodzenia; tamże: ID lviv_deaths_revised-22618, Tobias Lorje - akt zgonu, [online] https://search.geshergalicia.org [dostęp 29.03.2020].

6 Tamże: ID lviv_marriage_revised-4958, Berl Lorje i Jutte Schorr - akt matżeństwa, [online] https://search.geshergalicia.org [ [đostęp 29.03.2020].

7 M.F. Poremba (ur. 1818, zm. 1880) - lwowski drukarz, założyciel (w r. 1847) i właściciel (do r. 1876) drukarni zwanej od roku 1867 „Drukarnią Krajową”. Poza książkami drukował, między innymi, „Gazetę Narodową”, „Dziennik Polski” i „Rocznik Teatralny”.

8 Ch.B. Friedberg, Toldot ha-dfus ha-iwri be-Polania mi-reszit hiwasdo be-sznat 694 we-hitpatchuto ad zmanenu [Dzieje druku hebrajskiego w Polsce od jego początków w roku 1534 i jego rozwój do naszych czasów], wyd. II, Tel Awiw 1950, s. 85; Sz. Bednarski, Materyaty do historyi o drukarniach w Polsce, a mianowicie o drukarniach lwowskich i prowincyonalnych, Lwów 1888, s. 31.

$9 \quad$ A. Jakimyszyn, Żydowska ksiażka religijna drukowana we Lwowie $w$ drugiej połowie XIX i na poczatku XX stulecia, [w:] Lwów. Miasto - Społeczeństwo - Kultura. T. 9: Życie codzienne miasta, red. K. Karolczak i Ł.T. Sroka, Kraków 2014, s. 161.

10 Formy podane $\mathrm{w}$ nawiasie to spotykane $\mathrm{w}$ literaturze (i przyjęte nieraz przez osoby o tym nazwisku) zniekształcenia formy prawidłowej - Madpis (hebr.: madpis = drukarz).

11 Ch.B. Friedberg, dz. cyt., s. 66. 
fir Politik, Unterhaltung und Handel" (Posłaniec galicyjski: gazeta polityki, rozrywki i handlu), redagowany przez Menachema Mohra ${ }^{12}$.

W roku 1863 D.B. Lorje został wydawcą i zarządcą Drukarni Instytutu Stauropigialnego we Lwowie ${ }^{13}$. Pierwszą znaną wydaną we lwowskim Instytucie przez Lorję publikacją jest datowany na rok 1863 skorowidz Neu verbesserter Wegweiser der kön. Hauptstadt Lemberg... opracowany przez J. Slezińskiego. Następnie wydaje, między innymi: modlitewnik Birkat ha-mazon (Błogosławieństwo pożywienia, Lwów 1865) zawierający także opowieść pesachową; Sefer ha-bahir (Księga światłości, Lwów 1865), kabalistyczną księgę żyjącego na przełomie I i II w. n.e. w Izraelu tanaity Nechunii ben ha-Kany oraz księgę komentarzy Likutej ha-pardes (Zbiory z sadu, Lwów 1866) słynnego XI-wiecznego francuskiego rabina Szlomo ben Icchaka znanego jako Raszi. Ostatnią wydrukowaną przez Lorje we Lwowie publikacją (rok 1868) był dwuczęściowy zbiór ,pieśni ludowych (folks lieder) w języku mówionym wśród Żydów z krajów Polski i Mołdawii z tłumaczeniem na język hebrajski”, autorstwa ludowego poety Beniamina Wolfa Ehrenkranza Zbarażera, zatytułowany Makal noam (Laska łaskawości).

Wkrótce jednak cieszący się już liczącym kilkadziesiąt pozycji dorobkiem drukarskim i wydawniczym Lorje ponownie próbuje swych sił poza nasyconym drukarniami Lwowem i rozpoczyna działalność w Przemyślu, gdzie - jak dotąd - konkurencja w branży hebrajskich i jidyszowych publikacji w zasadzie nie istniała. Jeden z lwowskich drukarzy, Szczęsny Bednarski (ur. 1845, zm. 1913) opisuje tę kwestię następująco:

Stan naszych drukarń prowincyonalnych jest w ogóle świetniejszy od drukarń lwowskich, bo nie ma tam takiej konkurencyi, jaka jest we Lwowie, gdzie - z małymi wyjątkami - jeden drugiego pragnie pognębić, zrujnować, w obec klienteli jak najgorzej przedstawić, niejedną robotę bierze z osobistą nawet stratą - byle ją współkoledze odebrać, jego ośmieszyć a siebie wychwalić, itd. itd ${ }^{14}$.

Swą działalność w Przemyślu Lorje rozpoczął w drukarni należącej do kapituły biskupstwa greckokatolickiego mieszczącej się w budynku skasowanego klasztoru karmelitów bosych, na wzgórzu, przy ulicy Karmelickiej. Niewykluczone, że stało się tak dzięki jego wcześniejszym kontaktom z klerem greckokatolickim, nawiązanym w okresie współpracy z lwowskim Instytutem Stauropigialnym.

Pierwszą hebrajską księgę w Przemyślu D.B. Lorje wydrukował w roku 1869, gdy formalnym dzierżawcą drukarni kapitulnej był jeszcze (od

12 Abraham Menachem Mendel Mohr (ur. 1815, zm. 1868) - działający we Lwowie galicyjski uczony, literat, żurnalista, propagator idei żydowskiego oświecenia.

13 A. Siciak, Dzieje ksią̇ki w Przemyślu w okresie autonomii Galicji (1867-1914), Przemyśl 2012, s. 68.

14 Sz. Bednarski, dz. cyt., s. 78. 
1 VIII 1866 r.) przybyły do Galicji z Królestwa Węgier lwowski zecer Aleksander Lévay ${ }^{15}$. Była to księga responsów Tiferet Josef... (Chwała Józefa) „zawierająca pytania i odpowiedzi do czterech części Szulchan aruch" "16. Jej autorem był Józef Chanania Lipa Meisels (ur. 1823, zm. 1865), rabin Przemyśla w latach 1851-1865. Zawarte w księdze pytania i odpowiedzi zebrał po śmierci autora i opatrzył komentarzami zatytułowanymi Klil tiferet (Zwieńczenie chwały) syn rabina - Mojżesz Meisels (ur. 1845, zm. 1925), rabin Krzeszowa i dajan w Mościskach i w Przemyślu. Hebrajski napis na stronie tytułowej głosi, iż księga została wydrukowana „w urządzonej na nowo drukarni u szlachetnego i znamienitego pana Berisza Lorje ze Lwowa w świętej gminie Przemyśl”, podczas gdy niemiecki napis u dołu tejże strony brzmi: „Druck von A. Lévay”.

Fot. 1. J.Ch.L. Meisels, Tiferet Josef, Przemyśl 1869 - strona tytułowa.

Zdjęcie: K.D. Majus

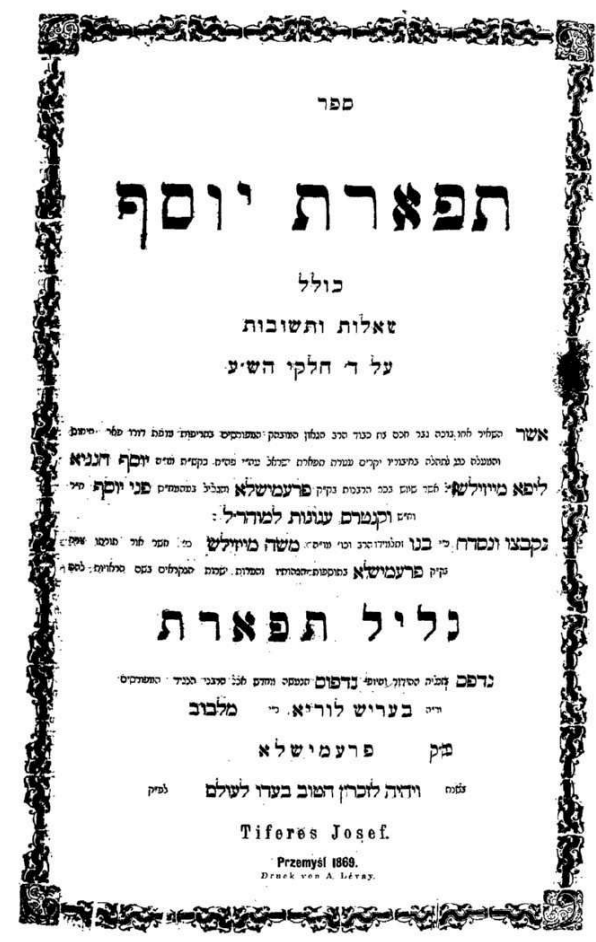

15 Aleksander Lévay - patrz biografia w: A. Siciak, dz. cyt., s. 64-67.

16 Szulchan aruch (Nakryty stół), wybitne dzieło sefardyjskiego rabina Józefa Karo (ur. 1488, zm. 1575), stanowiące prostą i jasną kodyfikację żydowskiego prawa religijnego. 
Wkrótce po wydaniu Tiferet ${ }^{17}$ Josef czteroletnia umowa dzierżawna A. Lévaya z kapitułą greckokatolicką uległa skróceniu o pół roku z powodu jego problemów finansowych i 1 II 1870 r. dzierżawę drukarni objął oficjalnie D.B. Lorje, wraz ze swym nowym wspólnikiem Judą Goldsternem ${ }^{18}$, podpisując umowę dzierżawną na trzy lata ${ }^{19}$. Obydwaj rozpoczęli w roku 1870 drukowanie dzieła składającego się z sześciu części, zatytułowanego Szirej tiferet (Pieśni chwały), obejmującego 18 pieśni religijnych opiewających wyjście Żydów z niewoli egipskiej, autorstwa znanego hamburskiego rabina Naftalego Herza Weisela (ur. 1725, zm. 1805). Dzieło to zostało wydane po raz pierwszy drukiem w Berlinie w latach 1789-1802 (cz. I-V) i w Pradze w roku 1829 (cz. VI). Dwie pierwsze części wydane w Przemyślu noszą nazwiska obydwu dzierżawców: „Schnellpreßdruck des B. Lorje et J. Goldstern in Przemysl" (Drukarnia pospieszna B. Lorje i J. Goldsterna w Przemyślu) i opatrzone są datą 1870. Kolejne cztery części wydrukowane zostały z przygotowanych wcześniej materiałów już w następnym roku przez następcę Lorji i Goldsterna, którym został Chaim Aron Żupnik.

Z końcem kwietnia 1870 r. obydwaj wspólnicy, Lorje i Goldstern, wypowiedzieli zawartą ledwie trzy miesiące wcześniej umowę dzierżawy, gdyż kapituła zdecydowanie odrzuciła zaproponowane przez nich przeniesienie drukarni bliżej centrum miasta, co ich zdaniem było niezbędne dla powodzenia przedsięwzięcia. Umowa przewidywała jednak półroczny okres wypowiedzenia, co pozostawiało dzierżawę w mocy do końca października $1870 \mathrm{r}$. W tym też miesiącu ${ }^{20}$ ukazuje się ostatnie z dzieł wydrukowanych przez D.B. Lorje w drukarni kapitulnej w Przemyślu - Mewaser cedek (Wieszczący prawość). Autorem obejmującej nowele toraniczne księgi był wieloletni rabin Złoczowa Issachar Dow Ber (1735-1795). Hebrajski napis na stronie tytułowej informuje, iż księga została wydrukowana przez ,pana Dowa Berysza Lorje”, a napis w języku niemieckim dodaje (zachowana pisownia oryginału): „Buchdrukeri der gr[iechisch] kat[olische] Domkapitel in Przemyśl".

Nie są znane żadne publikacje opatrzone nazwiskiem Lorje datowane po roku 1870, można więc założyć, że D.B. Lorje nie kontynuował już działalności

17 Zgodnie z zaleceniami jerozolimskiej Akademii Języka Hebrajskiego stosuję tu i w dalszej części artykułu zapis zgodny z wymową obowiązującą współcześnie w Izraelu („tiferet”) i opartą na wymowie Żydów jemeńskich, a nie z praktykowaną w środkowej i wschodniej Europie wymową Żydów aszkenazyjskich (,tiferes”), która została przejęta przez język polski w nazewnictwie przedmiotów związanych z religią mojżeszową. Dla przykładu, „tałes” - szal modlitewny, wymawiany jest we współczesnym hebrajskim jako ,talit”.

18 J. Goldstern, syn Herza i Lei z domu Menkes, urodził się we Lwowie w roku 1846. Brak innych informacji na jego temat.

19 A. Siciak, dz. cyt., s. 69.

20 Księga opatrzona jest gregoriańską datą 1870 i hebrajską datą 5631. Ponieważ rok 5631 wg kalendarza hebrajskiego rozpoczynał się 26 IX 1870, a dzierżawa Lorji i Goldsterna wygasała 31 X 1870, można sprecyzować wydanie księgi na październik $1870 \mathrm{r}$. 
drukarskiej ani wydawniczej i zapewne powrócił do Lwowa. Jego dalsze losy nie są znane. Zmarł przed rokiem 1894, o czym świadczy nadanie jego imienia urodzonemu w tymże roku wnukowi, synowi Joela Mojżesza Lorje.

\section{Chaim Aron Żupnik}

Następcą D.B. Lorji w branży hebrajskiego drukarstwa w Przemyślu został wspomniany już Ch.A. Żupnik. Ojciec Chaima Arona, Ezechiel (Chaskel) Żupnik, syn Abrahama i Frajdy (ur. 1798, zm. 1846), urodził się w roku 1817. Około roku 1840 Ezechiel poślubił urodzoną w 1821 r. Sarę Fajgę Freuer, córkę Izaaka (Eisiga) i Menuchy (Nichy). Ezechiel zmarł w Przemyślu w wieku 62 lat, 7 IX 1879 r., na zapalenie jelit (enteritis) i dwa dni później został pochowany na miejscowym cmentarzu żydowskim ${ }^{21}$. Po śmierci męża Sara Fajga znalazła się w bardzo trudnym położeniu ekonomicznym i była zmuszona utrzymywać się z żebractwa. Zmarła siedem lat po Ezechielu, w wieku 67 lat, 28 XI 1886 r., i została pochowana na miejscowym cmentarzu żydowskim ${ }^{22}$.

Ch.A. Żupnik urodził się w Przemyślu około roku 1843. Mając 20 lat poślubił urodzoną w tym samym mieście w roku 1845 Chaję Itę (Jüttę) Laufer, córkę Mojżesza i Tamary (Temy) z domu Taser. Małżeństwo to zostało potwierdzone oficjalnym, urzędowym ślubem zawartym 17 VI 1888 r. w Przemyślu, celebrowanym przez przemyskiego rabina Izaaka Szmelkesa ${ }^{23}$. Przemyski drukarz Chaim Aron (Ch.A. Żupnik) bywa czasem mylony ze swym kolegą po fachu i rówieśnikiem Aronem Hirszem (A.H. Żupnik) z Drohobycza (ur. w czerwcu 1843 w Samborze, zm. 1917 w Wiedniu) ${ }^{24}$. Obydwu łączyło nie tylko nazwisko, wiek i wykonywany zawód, ale zapewne także pewne pokrewieństwo, którego jednak nie udało się ustalić.

Początkowo Chaim Aron trudnił się w Przemyślu introligatorstwem, podobnie jak jego kuzyn Ber (Berysz) Żupnik. W pierwszej połowie 1871 r., mając 28 lat, przejął po dotychczasowych dzierżawcach, Lorji i Goldsternie, drukarnię przemyskiej kapituły greckokatolickiej i odkupił od nich sprzęt i wyposażenie. Drukarnia mieściła się nadal w budynku skasowanego klasztoru karmelitów bosych przy ulicy Karmelickiej, lecz w maju 1878 r. przeniesiona

21 Portal Jewish Record Indexing [dalej JRI] - Poland: Przemyśl, Deaths 1790-1899, akta 19, Freyde Zupnik - akt zgonu; tamże: akta 211, Chaskel Zupnik - akt zgonu, [online] https://www.jri-poland.org/jriplweb.htm [dostęp 8.04.2019].

22 Tamże: Przemyśl, Deaths 1790-1899, akta 273, Sara Feiga Zupnik - akt zgonu, [online] https://www.jri-poland.org/jriplweb.htm [dostęp 8.04.2019].

23 Tamże: Przemyśl, Marriages 1863-1899, akta 51, Chaim Aron Żupnik i Chaja Jita Laufer akt małżeństwa, [online] https://www.jri-poland.org/jriplweb.htm [dostęp 8.04.2019].

24 Tamże: Lwów, Marriages1870-1899, akta 83, Aron Żupnik i Feiga Rachel Lewin/Finsterbusch - akt małżeństwa, [online] https://www.jri-poland.org/jriplweb.htm [dostęp 8.04.2019]. 
została do centrum miasta i od tej pory działała przy rynku, do kwietnia $1894 \mathrm{r}$. pod numerem 63, a później pod numerem 2.

Pierwszą publikacją wydrukowaną przez Żupnika w $1871 \mathrm{r}$. były cztery ostatnie z sześciu części dzieła zatytułowanego Szirej tiferet. Na ostatniej stronie części szóstej widnieje zapis w języku hebrajskim: „W nowej drukarni pana [...] Chaima Arona Żupnika i jego wspólników w Przemyślu”. Na stronie tej widnieje również informacja, iż prace zecerskie przy wydaniu książki wykonał Pinchas Cwi Wassermann, syn błp. Józefa Samuela Wassermanna, a korekty dokonał Naftali Jakób Weinig ${ }^{25}$. Można więc założyć, że to oni byli ówczesnymi, nieformalnymi „wspólnikami” Żupnika.

Kolejna drukowana przez Żupnika księga, nosząca również datę 1871, opatrzona została napisem w języku hebrajskim: „W naszej nowej drukarni, tu w Przemyślu, pana Chaima Arona Żupnika i jego wspólników”, choć napis literami łacińskimi głosi tylko: „Buchdr[uck] der gr[iechisch] kat[olische] Dom-kapitel u[nter] L[eitung] J[ózef] Kraus”. Do nieformalnych „wspólników" dołączył więc Józef Kraus ${ }^{26}$. Księgą tą była Sefer Malkiel (Księga Malkiela) autorstwa żyjącego na przełomie XVI i XVII w. Malkiela Chezkji Aszkenazy i poświęcona ona jest jego imiennikowi, rabinowi Malkielowi Aszkenazy, który w roku 1540 odkupił od Karaimów tereny w położonym w Judei mieście Hebron $^{27}$, na których założył dzielnicę żydowską.

Chaim Aron nie dysponował najprawdopodobniej wystarczającymi środkami do prowadzenia samodzielnej działalności drukarskiej, gdyż pilnie poszukiwał wspólnika. Już w drugiej połowie 1871 r. Żupnik przyjął do spółki Chaima Knollera. Według dotychczasowego stanu wiedzy obydwaj wspólnicy, czyli Żupnik i Knoller, założyli w roku 1876 własną drukarnię (reskrypt gubernialny nr 22597/876). Sądzić należy, iż odbyło się to przez przejęcie nieczynnej już (działała w latach 1860-1872) typografii Michała Dzikowskiego ${ }^{28}$. Utrzymali przy tym jednak dzierżawę drukarni kapitulnej i drukowali książki w obydwu tych drukarniach ${ }^{29}$.

Datę uruchomienia własnej drukarni Żupnika i Knollera należy najprawdopodobniej przesunąć o dwa lata wstecz, gdyż już w roku 1874 ukazała się

25 N.J. Weinig (ur. 1830, zm. 1886), swat, kupiec i uczony w Piśmie z Przemyśla, syn przemyskiego dajana Dawida Weiniga, publikował artykuły w czasopismach oraz wydał w Przemyślu książki: Maszpil Geim [Poniżający dumnych], 1873; Szir ha-elef [Pieśń tysiąca], 1879; Diwrej emet [Słowa prawdy], 1883; oraz dwa utwory na cześć brytyjskiego ministra i filantropa Mojżesza Montefiori: elegię Szir ha-kawod [Pieśń szacunku] z okazji setnej rocznicy urodzin tejże osobistości (1884) i odę Tehila u-tfila [Pieśń pochwalna i modlitwa], (b.d.).

26 J. Kraus był zarządcą dzierżawionej drukarni do lutego 1892.

27 Hebron - obecnie miasto na terenie Autonomii Palestyńskiej.

28 M. Dzikowski - patrz biografia w: A. Siciak, dz. cyt., s. 77-80.

29 A. Siciak, Druki przemyskie 1754-1939. Bibliografia publikacji polskich, niemieckich, węgierskich, francuskich oraz żydowskich i ukraińskich wydanych alfabetem tacińskim, Przemyśl 2002, s. 29. 
co najmniej jedna księga pozbawiona informacji o wydrukowaniu jej w drukarni kapitulnej. Była to rozprawa talmudyczna Halacha le-Mosze (Prawo Mojżesza) napisana przez krakowskiego dajana Mojżesza Eliasza Neumüntza (ur. ok. 1770, zm. 1838), informująca na stronie tytułowej, iż została „,wydrukowana w Przemyślu, w drukarni pana Chaima Arona Żupnika i pana Chaima Knollera". Pozbawiona informacji o wydrukowaniu w drukarni kapitulnej była także jedna z ksiąg wydanych w roku 1872, a mianowicie Bchinat olam (Badanie świata) francuskiego rabina, poety i filozofa Jedaji Bedarsiego z miasta Béziers (ur. 1270, zm. 1340). Strona tytułowa tej księgi informuje w języku hebrajskim, iż została ona wydrukowana „w nowej drukarni pana Chaima Arona Żupnika”, a na jej odwrocie widnieje napis w języku niemieckim „Druck von A. Żupnik in Przemyśl”. Możliwe więc, że wspomniany reskrypt z roku 1876 potwierdził jedynie stan rzeczy istniejący już od co najmniej od dwu bądź nawet od czterech lat.

Fot. 2. J. Słowacki, Awi ha-nigafim..., Przemyśl 1883, strona tytułowa.

Zdjęcie: K.D. Majus

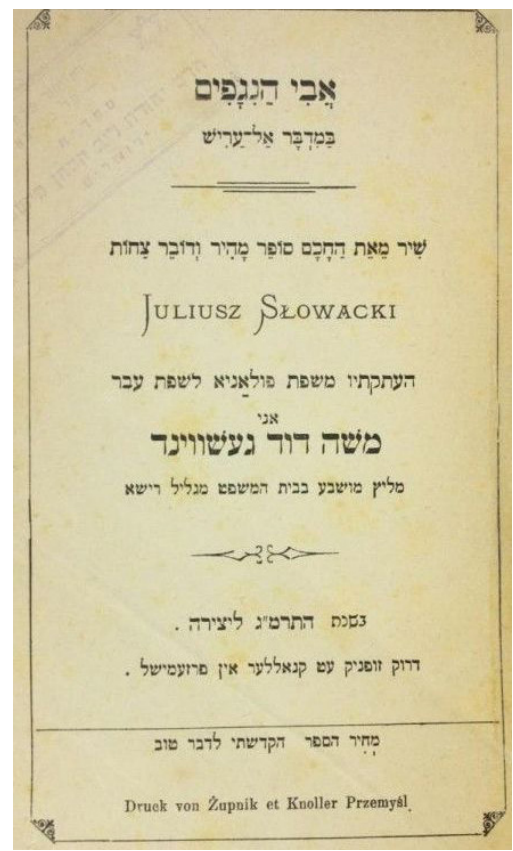

Niewątpliwą ciekawostką jest wydrukowanie przez Żupnika i Knollera w roku 1883 pierwszego w świecie hebrajskiego thumaczenia utworu Juliusza Słowackiego. Był to Ojciec zadżumionych w tłumaczeniu Mojżesza Dawida Geszwinda (1840-1905), „radcy przysięgłego w Sądzie Okręgowym Rzeszów", jak napisano na stronie tytułowej. Tłumaczenie to nosiło tytuł Awi 
ha-nigafim be-midbar El-Arisz (Ojciec zadżumionych na pustyni El-Arisz). Przemyska publikacja jest obecnie prawdziwym „białym krukiem”, gdyż już w lipcu roku 1939 autor artykułu o tymże thumaczeniu pisał: „W całej Polsce, o ile mi wiadomo, zachowały się dwa egzemplarze tej ciekawej i wyczerpanej publikacji: jeden w Bibliotece Judaistycznej przy Wielkiej Synagodze w Warszawie, drugi - w Bibliotece im. Straszuna w Wilnie" ${ }^{30}$.

Początkowo Żupnik był współwłaścicielem spółki tylko z Knollerem, lecz z początkiem roku 1883 dołączył do nich teść Knollera, Abraham Hammerschmidt, wraz ze swym synem Izraelem, co potwierdzono reskryptem gubernialnym L. 20972 z 16 IV 1883 r. Abraham zmarł osiem lat później, 24 VIII 1891 r., a jego część w spółce odziedziczył syn Izrael, który w roku 1896 odstąpił swą własną i odziedziczoną po ojcu część Meilechowi Wolfowi (odnośną zmianę do koncesji wprowadzono pod datą $13 \mathrm{~V} 1896$ r.), właścicielowi cegielni oraz domów, oficyn i placów w Przemyślu. Ten jednak po niecałych dwóch latach zrezygnował z udziału w spółce. Od roku 1898 spółka działała ponownie w pierwotnym, dwuosobowym składzie. Hammerschmidtowie i Wolf nie byli drukarzami ani z zawodu, ani z powołania, i traktowali spółkę drukarską wyłącznie jako przedsięwzięcie inwestycyjne, nie poświęcam więc im więcej miejsca.

\section{Knollerowie}

Knollerowie pochodzili z licznej religijnej rodziny mającej w Przemyślu korzenie sięgające co najmniej drugiej połowy XVIII w. Pierwszym członkiem rodziny, który zajął się drukarstwem był wspomniany już Ch. Knoller.

Ojciec Chaima, Dawid Knoller, syn Jechezkela znanego jako Chaskel (ur. 1793 w Przemyślu, zm. tamże 13 X 1872 r.) i Malki, urodził się w Przemyślu w wielodzietnej rodzinie w lutym $1820 \mathrm{r}$. W wieku osiemnastu lat Dawid poślubił 2 VII 1838 r. w Przemyślu Leę (Łaję) Dützen, urodzoną w roku 1819 córkę Hirsza Cwi (zm. 1862) i Chany. Dawid był szanowanym i dobrze sytuowanym obywatelem miasta Przemyśl. Od roku 1865 pełnił przez wiele lat funkcję ,zaprzysiężonego szacownika dla porcelany i fajansu” przy przemyskim sądzie obwodowym i kontrolera w zarządzie szpitala izraelickiego w Przemyślu. Zmarł w rodzinnym mieście 18 VIII 1903 r., a jego żona Lea -24 II $1885 r^{31}$

J. Warszawiak, Stowacki w języku Biblii, „Nasz Przegląd” 1939, nr 190, s. 19.

31 M. Wunder, Meorej Galicja. Enciklopedia le-chachmej Galicja (Meorei Galicia. Encyclopedia of Galician Rabbis and Scholars). T. 4, Jeruszalaim 1990, s. 573; Handbuch des Statthalterei-Gebiets in Galizien für das Jahr 1865, Lemberg 1865, s. 141, 489; Szematyzm królestwa Galicyi i Lodomeryi z wielkim księstwem krakowskiem na rok 1872, Lwów 1872, s. 108, 550; JRI - Poland: Przemyśl, Births 1789-1827, akta 18, Dawid Knoller - akt urodzenia; tamże: Marriages 1838-1848, 
Ch. Knoller urodził się w Przemyślu w roku 1847. W dniu 21 XII 1869 r. poślubił 22-letnią Deborę (hebr.: Dwora), córkę Abrahama i Chai Hammerschmidtów. Należał do wyznawców cadyków z Sieniawy i modlił się w domu modlitwy sieniawskich chasydów zwanym Klojzel (mały klojz) przy ulicy Serbańskiej. W latach 90. XIX w. i w pierwszej dekadzie XX w. zasiadał w dyrekcji zarejestrowanego w Przemyślu Towarzystwa Żyrowego i Kredytowego ${ }^{32}$. Mając zaledwie 25 lat zajął się drukarstwem, wchodząc w drugiej połowie 1871 r. w spółkę z Żupnikiem.

Pierwszą znaną księgą, w której figuruje nazwisko Knoller, była Riszon le-Cijjon (Pierwszy w Syjonie) wybitnego marokańskiego rabina Chaima ibn Attara (1696-1743), poświęcona nowelom do kilku traktatów talmudycznych. U dołu strony tytułowej księgi wydanej nie później niż we wrześniu $1871 \mathrm{r}^{33}$ widnieje niemiecki napis: „G[riechisch] K[atholische] Buchdruck u[nter] P[achtung] des Żupnik u[nd] Knoller u[nter] L[eitung] J[ózef] K[raus]", choć napis hebrajski wymienia tylko nazwisko Żupnika (,pan Chaim Aron Żupnik i jego wspólnicy").

Ch. Knoller działał nieprzerwanie w zmieniającej skład spółce ponad pół wieku, aż do swej śmierci, drukując w tym czasie w obydwu drukarniach, dzierżawionej i własnej, ponad 300 ksiąg religijnych i innych publikacji, włącznie z kalendarzami i księgami metrykalnymi dla gmin żydowskich. Po śmierci Żupnika w roku 1902 Knoller dookoptował do spółki swego 24-letniego syna Hirsza. Od tej pory działała ona nieprzerwanie aż do późnych lat 30. pod nazwą Knoller i Syn (bądź Chaim Knoller i Syn). Pierwszą księgą wydrukowaną wspólnie przez ojca i syna była wydana w roku 1902 Kahal chasidim he-chadasz (Nowa społeczność chasydów) I.D. Bera, zawierająca 200 chasydzkich opowieści. Strona tytułowa informowała w języku hebrajskim, iż księga wyszła z „drukarni pana Chaima Knollera i Syna”, choć na jej odwrocie widnieje bardziej ogólna informacja alfabetem łacińskim: Knoller \& Comp.

Ch. Knoller był nie tylko cenionym drukarzem, ale również - a może przede wszystkim - autorem prawie 20 wydanych w Przemyślu ksiąg religijnych. Także to powodowało zapewne, że z czasem coraz więcej obowiązków związanych

akta 2, Dawid Knoller i Sara Dutzen - akt małżeństwa; tamże: Deaths 1790-1899, akta 58, Lea Knoller - akt zgonu; Chaskel Knoller - akt zgonu, s. 158, [online] https://www.jri-poland.org/jriplweb.htm [dostęp 19.11.2019].

32 N. Ulmer, Statystyka stowarzyszeń zarobkowych i gospodarczych w Galicyi z W. Księstwem Krakowskiem za rok 1894, Lwów 1895, s. 33; tegoż, Statystyka ... za rok 1895, Lwów 1896, s. 36; tegoż, Statystyka ... za rok 1908, Lwów 1909, s. 74; H. Trau, Ha-klojz ha-gadol we-klojzlech [Wielki klojz i małe klojzy], [w:] Sefer Pszemiszl (Przemyśl Memorial Book), red. A. Menczer, Tel Awiw 1964, s. 126; JRI - Poland: Przemyśl, Marriages 1863-1899, akta 86, Chaim Knoller i Debora Hamerschmidt - akt ślubu, [online] https://www.jri-poland.org/jriplweb.htm [dostęp 19.11.2019].

33 Hebrajski chronogram podaje rok 5631, a 16 IX 1871 r. rozpoczął się już według kalendarza hebrajskiego rok 5632. 
z prowadzeniem drukarni przekazywał swemu synowi, by poświęcić się zbożnemu dziełu tworzenia i pisania. Pierwszym i być może najważniejszym jego dziełem było wydane w roku 1883 Pri chaim (Owoc życia), poświęcone komentarzom i objaśnieniom do Gemary, czyli drugiej części Talmudu. Odbiło się ono na tyle szerokim echem w świecie rabinicznym, że przyjętym wówczas zwyczajem zwano często jego autora nie imieniem i nazwiskiem, lecz tytułem książki: Pri Chaim. W następnych latach ukazywały się kolejne księgi Knollera, będące najczęściej komentarzami i objaśnieniami do różnych części Biblii i Talmudu: Megilat Szir ha-Szirim (Księga Pieśń nad Pieśniami) w 1890, wznowiona w 1894 r.; Megilat Kohelet (Księga Koheleta) w 1891, wznowiona w 1896; modlitewnik Daat kdoszim (Mądrość świętych) - 1892; Megilat Eicha (Księga Lamentacji) i Megilat Rut (Księga Rut) - 1893; Megilat Ester (Księga Estery) - 1894; Kwod chachamim (Chwała mądrych) - 1898; Ben cheled (Człek świata) - 1900, Dwar jom be-jomo (Codzienna porcja) - 1907, wznowiona w 1933; komentarze Pri Chaim do pięciu ksiąg Tory: Bereszit (Księga Rodzaju) - 1918, Szemot (Księga Wyjścia) i Wa-Jikra (Księga Kapłańska) - 1920, Ba-Midbar (Księga Liczb) - 1922 i Dwarim (Księga Powtórzonego Prawa) - 1924; oraz Birkat ha-chama le-sznat 5685 (Błogosławieństwo słońca na rok 1924/25) - 1924 i Masechet Awot (Traktat Ojców) - 1925. Ostatnie dwa jego dzieła ukazały się już pośmiertnie. Midrasz Raba al ha-Tora (Wielki Komentarz do Tory) w roku 1932 i Perusz al Midrasz Raba (Interpretacja do Wielkiego Komentarza) w roku 1936.

Ch. Knoller zmarł w Przemyślu 4 VIII 1927 r. Jego pogrzeb, który zgodnie z zasadami religii żydowskiej odbył się jeszcze tego samego dnia wieczorem, zgromadził liczne rzesze żałobników. W lwowskim miesięczniku fachowym zamieszczono obszerny nekrolog, który przytaczam z niewielkimi tylko skrótami, zachowując pisownię oryginału:

Knoller Chaim, właściciel jednej z najstarszych drukarń w Przemyślu, a zarazem długoletni dzierżawca drukarni grecko-kat. Kapituły, zmarł 4 sierpnia b.r. w sędziwym wieku, przeżywszy lat 80.

Zmarły znany był jako człowiek wielkiej nauki w zakresie żydowskiej teologii i cieszył się ogromnym szacunkiem nie tylko wpośród współwyznawców-talmudystów, lecz także w sferach kupiectwa i obywatelstwa katolickiego w Przemyślu. Z drukarni bł. p. Knollera, istniejącej od lat 60 -ciu wyszły dziesiątki dzielnych pracowników. W pośród pracowników drukarskich cieszył się Zmarły ogromnem poważaniem, zdobywając sobie opinję sprawiedliwego pracodawcy, pragnącego zawsze wszelkie spory i konflikty, jakie niejednokrotnie życie powodowało między pracownikami a pracodawcami, zażegnać drogą rozumnej ustępliwości i porozumienia, to też ogół pracujących drukarzy w Przemyślu, chcąc oddać ostatnią przysługę Zmarłemu [...] zgromadził się u wylotu ulicy Słowackiego i oczekiwał nadejścia żałobnego konduktu [...], a któremu towarzyszyły tysiące współwyznawców nauki talmudystycznej, oraz liczna rzesza przyjaciół i znajomych Zmarłego. 
Na cmentarzu żydowskim nad mogiłą przemawiał p. Józef Styfi, właściciel drukarni, który scharakteryzowawszy życie bł.p. Knollera oraz stosunki zawodowe jakie łączyły go ze Zmarłym wówczas, kiedy pracował w Jego drukarni, we wzruszających słowach pożegnał zwłoki słowami: „Żegnaj mi mój pryncypale - do widzenia, wkrótce się zobaczymy”. Cześć Jego pamięci! $!^{34}$

Po śmierci Chaima samodzielne prowadzenie drukarni przejął jego syn Hirsz, pozostawiając jednak dotychczasową nazwę firmy Knoller i Syn. Pod kierownictwem Hirsza drukarnia zdecydowanie ograniczyła działalność i wydała zaledwie kilka hebrajskich ksiąg i książek. Były to głównie księgi napisane przez jego ojca: Midrasz Raba w roku 1932 i wznowienie w 1936 oraz wznowienie Pri chaim w roku 1936, a także kilka popularnych książek przemyskiego działacza syjonistycznego Abrahama Kahany (ur. 1889, zm. 1954), takich jak Szirej gola we-geula (Pieśni diaspory i zbawienia; 1933), Masot al sofrim u-anszej szem (Eseje o pisarzach i sławnych ludziach; 1934) czy Sefer ha-bdichot we-ha-halacot (Księga żartów i dowcipów; 1935).

W drugiej połowie lat 30. XX w. H. Knoller wraz z żoną Bejlą Rachelą opuścił Polskę i wyjechał do Izraela zwanego wówczas Palestyną i będącego do maja 1948 r. brytyjskim terytorium mandatowym. Zarządzanie drukarnią pozostawił zięciowi, mężowi swej córki Sary, Szymonowi Wilhelmowi Miesesowi, który jednak nie prowadził już prawie żadnej działalności drukarskiej. Szymon Wilhelm urodził się 23 IX 1891 r. we Lwowie przy ulicy Szpitalnej 4. Był synem ajenta handlowego Mojżesza Miesesa (ur. III 1850 r. - zm. 7 I 1900 r.) i Fajgi Lei z domu Schilder (ur. IV 1860 r.), którzy oficjalny ślub zawarli we Lwowie 15 I 1893 r., półtora roku po urodzeniu Szymona. Szymon i Sara Miesesowie zamierzali także wyjechać do Izraela, lecz wybuch II wojny światowej uniemożliwił im to i obydwoje zginęli w nieznanych bliżej okolicznościach ${ }^{35}$.

Hirsz (Cwi) Knoller zmarł 29 XI 1952 r. w Hajfie w wieku 74 lat i został pochowany na cmentarzu Hof ha-Karmel. Jego żona, Bejla Rachela, zmarła w Hajfie 10 VI 1961 r. i została pochowana na tym samym cmentarzu.

\section{Schwarzowie}

W Przemyślu działała także drukarnia Schwarza i Robinsohna. Autor rozdziału poświęconego drukarniom w przemyskiej Księdze Pamięci pisze

34 [Nekrolog Chaima Knollera], „Ognisko” 1927, nr 9, s. 3.

35 D. Nitzani, Batej dfus iwriim be-Pszemiszl [Hebrajskie drukarnie w Przemyślu], [w:] Sefer Pszemiszl..., dz. cyt., s. 89; JRI - Poland: Lwów, Births 1877-1899, akta 1082, Simon Wilhelm Mieses/Schilder - akt urodzenia; tamże: Marriages 1870-1899, akta 7, sygn. 651, Mozes Moses r. Prochnik i Fani r. Feige Lea Schilder r. Bath - akt małżeństwa, [online] https://www.jri-poland.org/ jriplweb.htm [dostęp 3.02.2020]; Portal Bractwa Pogrzebowego w Hajfie, [online] http://kdh.org.il [dostęp 4.02.2020]. 
co prawda, iż „zajmowała się ona szczególnie drukami w językach miejscowych, a po hebrajsku drukowano prawie wyłącznie ogłoszenia i różne druki na potrzeby handlu"36, jednak rzeczywistość była nieco inna, gdyż w latach 19101932 firma Schwarz i Robinson wydrukowała co najmniej 50 pozycji w jidysz i po hebrajsku. Ponieważ jednak było to znacznie mniej niż w drukarni Żupnika i Knollerów, poświęcam jej właścicielom krótsze wzmianki.

Dawid Leon Schwarz, znany pod swym drugim imieniem, urodził się około roku 1830 w Jarosławiu. Poślubił Chaję z domu Baumgarten ${ }^{37}$. W roku 1867 przeniósł się do Przemyśla, gdzie założył pierwszy w mieście antykwariat, prowadząc go wraz z żoną. L. Schwarz był szanowanym obywatelem Przemyśla, piastował różne funkcje społeczne, między innymi był sędzią przysięgłym (1878). W roku 1885 został wybrany do rady miejskiej. Od roku 1903 zasiadał w Radzie Nadzorczej Stowarzyszenia Bankowego dla Handlu i Przemysłu w Przemyślu. Był właścicielem domów przy ulicy Władycze 18 i 20 oraz nowej kamienicy przy Grodzkiej $15^{38}$. Będąc już w dość podeszłym wieku rozpoczął w roku 1890 tworzenie drukarni w tejże kamienicy przy Grodzkiej 15. Pierwsze druki ukazały się niej w roku $1891 \mathrm{i}$ były sygnowane przez firmę „Leon Schwarz i Spółka”. Spółkę tę zawiązał ze Stanisławem Trojanem - wykwalifikowanym drukarzem posiadającym ważną koncesję na prowadzenie drukarni. Przemiana z księgarza w drukarza i spółka z Trojanem nastąpiły zapewne za namową syna, Filipa, który postąpił podobnie pięć lat wcześniej w Samborze. Nie później niż od roku 1902 zarządcą drukarni Schwarza był Jan Hryndzio-Hrynkiewicz, wydawca i redaktor odpowiedzialny drukowanego w niej od roku 1903 „Nowego Głosu Przemyskiego”. W maju 1902 r. Schwarz wydzierżawił drukarnię Klemensowi Robinsohnowi i Mojżeszowi Beglückterowi ${ }^{39}$.

Jedynym, ale za to ważnym, hebrajskim dziełem wydrukowanym w roku 1903 przez Schwarza był zamówiony przez przemyskich wydawców, Etel Amkraut i Simchę Freunda, przedruk pięciotomowej księgi Mikraot Gdo$l o t^{40}$, wydanej uprzednio w Przemyślu w roku 1899 i drukowanej wówczas przez Żupnika i Knollera. Co ciekawe, Schwarz nie sygnował swej pracy ani nieużywanym przez niego na co dzień hebrajskim imieniem Dawid, ani też

\footnotetext{
36 Nitzani, dz. cyt., s. 89.

37 JRI - Poland: Sambor, Marriages 1877-1914, akta 21, page 1097, Fischel v. Filip Schwarz i Hania Wiesenberg - akt ślubu, [online] https://www.jri-poland.org/jriplweb.htm [dostęp 24.03.2020].

38 A. Siciak, Druki przemyskie..., dz. cyt., s. 106-108.

39 „Echo Przemyskie” 1902, nr 28, s. 3.

40 Termin Mikraot Gdolot (Wielkie Księgi) oznacza specjalne wydania Biblii hebrajskiej, złożone z czterech zasadniczych elementów: oryginalny, hebrajski tekst Biblii; krótkie uwagi do tekstu; tłumaczenie na język aramejski (tzw. Targum); oraz rozbudowane komentarze biblijne. Nazwę zaczerpnięto od tytułu pierwszego ułożonego w ten sposób drukowanego wydania Biblii (Wenecja 1516-17).
} 
grecko-łacińskim Leon, lecz jego hebrajskim odpowiednikiem Arie (obydwa znaczą „lew”). Wkrótce po wydaniu tego dzieła L. Schwarz zmarł. Nastąpiło to w Przemyślu 21 VI 1904 r. W nekrologu wydrukowanym w lokalnej gazecie, napisano:

Zmarły od wielu lat osiadły w Przemyślu z małych początków dorobił się własną pracą znacznego majątku i poważania. Znaną swoją, najstarszą w Przemyślu antykwarnię i handel papieru prowadził sam, mimo podeszłego wieku, do ostatnich dni życia $[\ldots]^{41}$.

Po śmierci dotychczasowego właściciela drukarnia przeszła w ręce jednego z jego trzech synów, Filipa, pomimo że firmę „Leon Schwarz i Spółka” wykreślono z rejestru sądowego dopiero 1 III 1911 r. Fiszel Filip Schwarz, znany pod swym drugim imieniem, urodził się w roku $1853 \mathrm{w}$ Tarnawie ${ }^{42}$. Po przeniesieniu się w roku 1867 wraz z rodzicami z Jarosławia do Przemyśla uczęszczał do miejscowego gimnazjum. Był dwukrotnie żonaty. W roku 1880 poślubił w Jarosławiu trzy lata młodszą Jeanettę Henriettę z domu Praus i wraz z nią zamieszkał w Samborze. 15 II 1887 owdowiał i 18 VII 1889 r. poślubił w Samborze młodszą o 16 lat Hanię z domu Wiesenberg, urodzoną w Sądowej Wiszni. W Samborze prowadził księgarnię, a w roku 1885 założył tam drukarnię wraz ze wspomnianym już wykwalifikowanym drukarzem, S. Trojanem. Po śmierci ojca powrócił do Przemyśla, by zająć jego miejsce jako właściciela drukarni.

Fot. 3. Ogłoszenie firmy Schwarz i Robinsohn („Nowy Głos Przemyski” z 22.07.1906). Źródło: „Nowy Głos Przemyski” z 22.07.1906. Zdjęcie: K.D. Majus

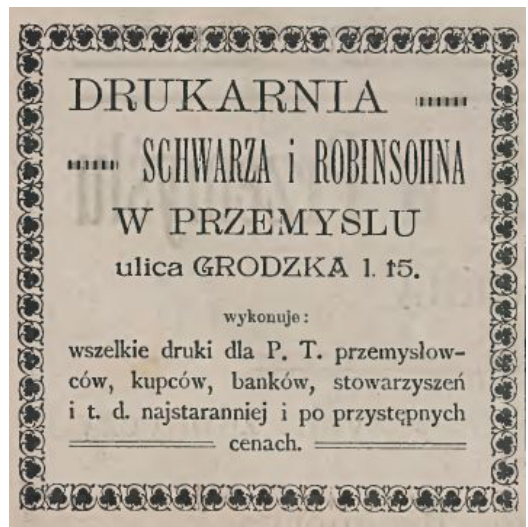

41 „Nowy Głos Przemyski” 1904, nr 17, s. 1.

42 JRI - Poland: Jarosław, Marriages 1877-1881, akta 5, Fischel Phillip Schwarz i Henriette Prans - akt małżeństwa; tamże: Sambor, Marriages 1877-1914, akta 21, page 1097, Fischel v. Filip Schwarz i Hania Wiesenberg - akt ślubu, [online] https://www.jri-poland.org/jriplweb.htm [dostęp 24.03.2020]. 
Śmierć M. Beglücktera spowodowała, że jego współdzierżawa drukarni ustała jeszcze przed jej formalnym wygaśnięciem z końcem $1906 \mathrm{r} \cdot{ }^{43}$ Po śmierci Beglücktera K. Robinsohn przyjął propozycję nowego właściciela i przystąpił z nim do spółki jako wspólnik. Nowa firma przyjęła nazwę „Schwarz i Robinsohn, drukarnia i handel papieru w Przemyślu”. Wychodzące z niej druki opatrywano nazwą „Drukarnia Schwarza i Robinsohna”. Pierwsze znane ogłoszenie tej firmy ukazało się w lipcu $1906 \mathrm{r}$.

F. Schwarz zmarł w Przemyślu 8 XI 1927 r. na zapalenie płuc. Pogrzeb odbył się nazajutrz ,przy udziale wszystkich pracowników drukarń, personelu tejże drukarni oraz licznej publiczności”44.

\section{Klemens Robinsohn}

Kalman Klemens Robinsohn, znany pod swym drugim imieniem, wspó1dzierżawca drukarni od maja 1902 i jej współwłaściciel od 1 I 1907 r., urodził się w styczniu 1861 r. w Samborze. Był synem Saula i Racheli Fajgi z domu Herschfeld. W dniu 18 VIII 1885 r. ożenił się w Przemyślu z dwa i pół roku młodszą, urodzoną tamże Reginą z domu Langbank ${ }^{45}$. Zanim zajął się drukarstwem był współwłaścicielem działającej od 13 VIII 1901 r. firmy „Sprzedaż maszyn do szycia i towarów mieszanych w Przemyślu Robinsohn \& Furth". Pełnił różne funkcje społeczne, między innymi na walnym zgromadzeniu Stowarzyszenia Kupców w Przemyślu (w marcu 1893 r.) wybrano go wydziałowym. Od roku 1905 był członkiem Rady Nadzorczej Stowarzyszenia Bankowego dla Handlu i Przemysłu w Przemyślu i w 1918 r. został tam zastępcą prezesa $^{46}$. W roku 1908 został prezesem Związku Syjonistów w Przemyślu. Ponadto pełnił obowiązki kasjera powstałej 22 VI 1921 r. komisji sanitarnej, działającej w ramach amerykańskiej organizacji Joint Distribution Comittee, mającej na celu poprawę warunków higienicznych i podniesienie stanu zdrowotnego ludności żydowskiej po I wojnie światowej ${ }^{47}$.

Firma Schwarz i Robinsohn wydrukowała w okresie 1910-1931 kilka publikacji religijnych w języku hebrajskim, takich jak Hagada szel Pesach (Opowieść pesachowa; m.in. edycje z 1910 i 1925), Ohalej Szem (Namioty Pana; 1929), Irin kdiszin (Święci czuwający) I. Friedmana (ok. 1930) czy Dower szalom (Piewca pokoju) A.C.S.B. Michelsona (1930). Były to głównie wznowienia wcześniejszych wydań. Znacznie więcej publikacji, bo ponad 30,

43 A. Siciak, Druki przemyskie..., s. 109.

44 „Ognisko" 1927, nr 12, s. 5.

45 JRI - Poland: Przemyśl, Marriages 1863-1899, akta 13, Kalman/Klemens Robinsohn i Regina Langbank - akt ślubu, [online] https:/www.jri-poland.org/jriplweb.htm [dostęp 24.03.2020].

46 N. Ulmer, Statystyka ... za rok 1912, Lwów 1913, s. 106.

47 Szpital żydowski w Przemyślu (Księga jubileuszowa) 1924-1934, Przemyśl 1935, s. 13-14. 
wydrukowano w jidysz. Były to przede wszystkim opowiadania historyczne i dramaty J. Kreppela, M. Goldbauma, I. Goldberga i J. Gordina. Jednak niewątpliwie najważniejszym, sztandarowym dziełem firmy Schwarz i Robinsohn na polu religijnej literatury hebrajskiej było wydrukowanie wydanego przez S. Freunda w końcu 1931 r. wielkiego pięciotomowego dzieła Józefa Miesesa (1882-1941), przemyślanina, doktora filozofii i literatury, naczelnego rabina Wojska Polskiego w latach 1922-1931. Dziełem tym, które zapisało się na trwałe wśród polskich thumaczeń biblijnych, był Pięcioksiąg Mojżesza wraz $\mathrm{z}$ thumaczeniem na język polski.

Fot. 4. Pięcioksiag Mojzesza, Księga pierwsza, Genesis, w języku hebrajskim z przekł. pol. J. Miesesa, Przemyśl 1931 - strony tytułowe. Zdjęcie: K.D. Majus

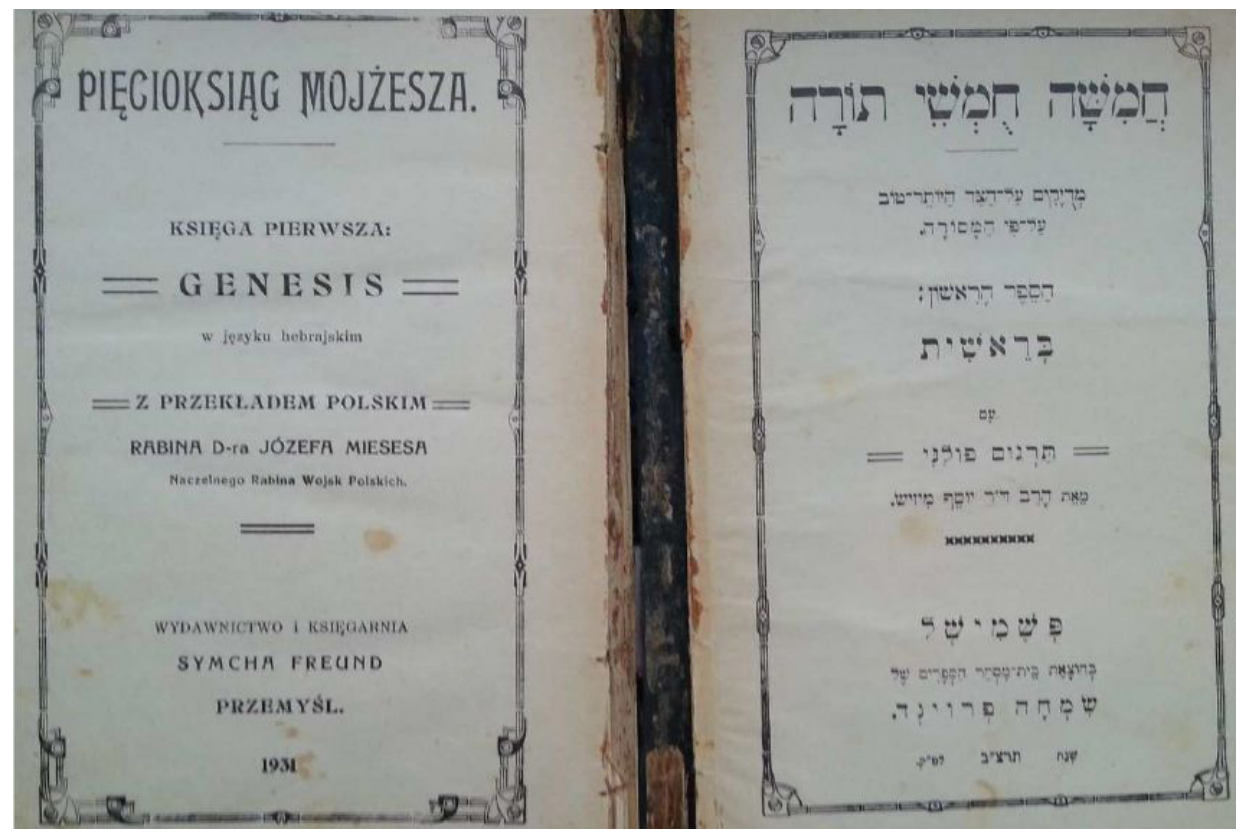

K. Robinsohn zmarł w Przemyślu 8 V 1933 r. Klepsydra autorstwa przemyskich drukarzy głosiła:

Gremjum właścicieli drukarń w Przemyślu zawiadamia o śmierci swego nieodżałowanego Kolegi bł.p. Klemensa Robinsohna, który zmarł w 72. roku życia. Pogrzeb odbędzie się we wtorek, dnia 9. maja b.r. o godz. X-tej popołudniu z domu żałoby przy ul. Moniuszki 8, na cmentarz tutejszy. Przemyśl, dnia 9. maja $1933^{48}$.

48 Archiwum Państwowe w Przemyślu, sygn. 56/397/0/0/3829. 
Znana jest także $\mathrm{z}$ ustnych relacji informacja o istnieniu w Przemyślu od roku 1928 drukarni Mojżesza Pipesa i Józefa Hammerlinga, wraz ze wzmianką, iż „tłoczyła druki w językach polskim i ukraińskim”49. Ponieważ nie są znane żadne publikacje $\mathrm{w}$ językach jidysz i hebrajskim, które miałyby być w tej oficynie drukowane, a ponadto informacja o istnieniu tej drukarni nie znajduje potwierdzenia w innych źródłach, pozostawiam jej ewentualnych właścicieli bez nawet pobieżnego omówienia.

\section{Wydawcy}

\section{Amkrautowie}

Najbardziej znana i zasłużona rodzina przemyskich wydawców hebrajskich i żydowskich ksiąg to Amkrautowie. Rodzinną epopeję wydawniczą zainicjował Aleksander Chaim, znany pod żydowskim zdrobnieniem pierwszego imienia - Sender. Urodził się w roku 1831. Jego rodzicami byli Józef Juda Lejbisz Amkraut (syn Eliasza Amkrauta z Rzeszowa) oraz pochodząca z Rzeszowa Sara Rajzel. Nie później niż w roku 1857 Sender poślubił Elkę, córkę Samuela Blumena i Estery Lei z Rzeszowa, choć formalny ślub zawarli przed I. Szmelkesem, ówczesnym rabinem Przemyśla, dopiero 27 XI 1876. S. Amkraut zmarł w wieku 57 lat w Przemyślu w roku $1888^{50}$.

Nie wiemy, czym S. Amkraut trudnił się w pierwszych dekadach swego życia, poza tym, że był wyróżniającą się w Przemyślu postacią wśród chasydów cadyka Dawida Szapiry z Dynowa (ur. 1804, zm. 1874) ${ }^{51}$. Działalność wydawniczą rozpoczął mając już prawie 50 lat, w roku 1877, o czym świadczy informacja zawarta na ostatniej, niepaginowanej stronie niektórych książek (m.in. Or Israel, Ohalej Szem, Sziwchej Baal Szem Tow) wydawanych w końcu lat 20. XX w. przez S. Freunda, następcę i ostatniego kontynuatora pracy wydawniczej Amkrautów.

Znana jest jak dotąd tylko jedna książka wydana przez Sendera. Jest to wydrukowane przez Żupnika i Knollera w roku 1878 dzieło rabina Leszna, Dawida Tewela (zm. 1792), noszące tytuł Nefesz Dawid (Dusza Dawida). Wybór tego właśnie dzieła nie był przypadkowy, gdyż D. Tewel był prapradziadkiem Sendera w linii męskiej. W dolnej części strony tytułowej publikacji znajdujemy informację w języku hebrajskim, w której wydawca upamiętnił łańcuch swych

49 A. Jagusztyn, Drukarstwo..., s. 136.

50 D. Tewel, Nefesz Dawid [Dusza Dawida], Przemyśl 1878, s. tytułowa; JRI - Poland: Przemyśl, Marriages 1863-1899, page 66, Sender Amkraut i Elke Blumen - akt ślubu, [online] https:// www.jri-poland.org/jriplweb.htm [dostęp 24.03.2020].

${ }_{51}$ M. Wunder, Meorej Galicja... T. 1, Jeruszalaim 1978, s. 223; T. 6, tamże 2005, s. 100. 
przodków wiodący aż do autora księgi: „Do drukarni dostarczyłem ja, wnuk autora Aleksander Sender Chaim, syn Józefa Judy Lejbisza, syna błp. Eliasza Amkrauta z gminy Rzeszów, syna błp. Jakuba, syna błp. autora". Alfabetem łacińskim zamieszczono tylko lakoniczne: „Verlag Sender Amkraut”. Po wydaniu Nefesz Dawid Sender przekazał zbożne dzieło publikowania kolejnych ksiąg religijnych w ręce starszego syna, mającego wówczas nieco ponad 20 lat Jakuba Mojżesza Amkrauta.

Fot. 5. Informacja na ostatniej, niepaginowej stronie niektórych publikacji S. Freunda, „Założono w roku 1877. Wydawnictwo i księgarnia Symcha Freund, Przemyśl”. Zdjęcie: K.D. Majus

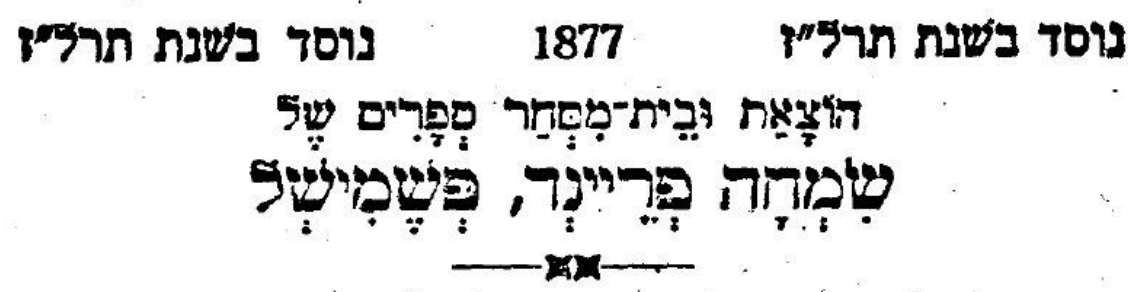

Jakub Mojżesz urodził się w Przemyślu w roku 1857. Od co najmniej 1882 r. był żonaty z Etel, urodzoną w roku 1862 w Jaryczowie córką Izaaka Landaua z Przemyśla i Goldy Racheli z domu Heszeles, jednak formalny ślub przed rabinem I. Szmelkesem został zawarty dopiero 15 II $1891 \mathrm{r}^{52}$ Początkowo trudnił się tylko prowadzeniem księgarni, w której sprzedawał księgi religijne i wybrane dewocjonalia (,sprzedawca książek, tałesów i atar w mieście Przemyśl") ${ }^{53}$. Najprawdopodobniej odziedziczył to zajęcie po ojcu, lecz brak na to wyraźnego potwierdzenia.

Pierwszą wydaną przez Jakuba Mojżesza księgą było poświęcone Księdze Abdiasza dzieło Klej ha-roim (Narzędzia widzących) słynnego Cwi Elimelecha Szapiry (ur. 1783, zm. 1841), założyciela dynastii cadyków dynowskich, ojca Dawida Szapiry. Zostało ono wydrukowane w przemyskiej drukarni Żupnika, Knollera i Hammerschmidta w początkach roku 1883. Kolejnym owocem jego pracy było zajmujące się przyszłą odbudową Świątyni Jerozolimskiej dzieło Maase choszew (Dzieło myślącego), napisane przez włoskiego rabina Rafaela Emanuela Chaja Ricchiego (1688-1743). Pierwsza jego edycja ukazała się w Wenecji w roku 1716, a wydanie przemyskie zostało wydrukowane w ostatnim kwartale 1883. J.M. Amkraut zdążył wydać tylko pięć dzieł religijnych.

52 JRI - Poland: Przemyśl, Marriages 1863-1899, akta 17, Jakób Mojżesz Amkraut i Etla Landau - akt ślubu, [online] https://www.jri-poland.org/jriplweb.htm [dostęp 24.03.2020].

53 „Hawacelet” 1890, nr 27, s. 8. 
Poza wspomnianymi powyżej opublikował w roku 1883 Or ha-chaim (Światło życia) wygnanego w roku 1492 z Portugalii i żyjącego później we Włoszech rabina Józefa Jafeca (ur. ok. 1440, zm. 1508). Pierwsze wydanie tego dzieła ukazało się w Ferrarze w roku 1554, a jedno z wielu wznowień w Przemyślu w roku 1873 (nakładem J.M. Rosenfelda). W roku 1884 ukazało się Mlo ha-roim (Tłum pasterzy) Jakuba Cwi Jolesa (ur. 1778, zm. 1825), rabina w Dynowie i Głogowie, a w roku 1885 dzieło Imrej bina (Słowa rozumne) rabina Buska i Gwoźdźca, Izraela Mateusza Auerbacha (ur. 1839, zm. 1900). Wszystkie pięć ksiąg zostało wydrukowanych w drukarni Żupnika, Knollera i Hammerschmidta.

J.M. Amkraut utrzymywał ożywione kontakty zawodowe z innymi wydawcami ksiąg religijnych. W lwowskim tygodniku „Machzikej ha-dat” informował czytelników i ostrzegał ich przed nieuczciwymi sprzedawcami (szczególnie tymi z Warszawy!), informując, iż jest jedynym na całą Galicję licencjonowanym przedstawicielem znanego wileńskiego wydawnictwa „Wdowa i Bracia Romm" ${ }^{54}$. W jerozolimskiej Bibliotece Narodowej przechowywana jest część jego korespondencji z Salomonem Buberem (ur. 1827, zm. 1906), lwowskim uczonym w Piśmie, wydawcą i bankowcem ${ }^{55}$. Mając 30 lat zajął się opracowywaniem swego najważniejszego dzieła, którym było wydanie liczącego ponad 600 stron modlitewnika według rytu sefardyjskiego. Modlitewnik opatrzony był rozbudowanym komentarzem zatytułowanym Tfila le-Mosze (Modlitwa do Mojżesza), autorstwa wybitnego kabalisty z Safedu w Galilei, Mojżesza Kordowero (ur. 1522, zm. 1577). Jakub Mojżesz ogłaszał się nawet w tej sprawie w hebrajskim dwutygodniku wychodzącym w Jerozolimie:

Ogłoszenie. Zwracam się do mych braci, synów Izraela, gdziekolwiek się znajdują. Być może jest w waszym posiadaniu jakaś kopia modlitewnika Tfila le-Mosze błogosławionej pamięci rabina Mojżesza Kordowero, w całości lub w części, lub manuskrypt którejś z jego ksiąg składających się na tenże modlitewnik. Proszę o jak najszybsze powiadomienie mnie o tym, a Pan po wielokroć wynagrodzi to wam. Pracuję nad wydaniem tegoż modlitewnika i pragnę aby było ono jak najdokładniejsze i najwierniejsze.

Jakub Mojżesz Amkraut, sprzedawca książek, tałesów i atar w mieście Przemyśl (Galicja). Adres: J.M. Amkraut, Przemisl, Galizien ${ }^{56}$.

Jakub Mojżesz Amkraut nie doczekał wydania swego sztandarowego dzieła, gdyż zmarł niespodziewanie, w wieku zaledwie 34 lat, we własnym domu przy ulicy Jagiellońskiej 446 na zapalenie płuc, we wtorek, 20 X 1891 r. Pogrzeb na przemyskim cmentarzu żydowskim odbył się dwa dni później ${ }^{57}$.

\footnotetext{
54 „Machzikej ha-dat” 1888, nr 9, s. 8.

55 The National Library of Israel, The Leopold Zunz Archives, ARC 4 1222-72.1 do 72.6 oraz 73.1 do 73.7. Listy J.M. Amkrauta do Salomona Bubera datowane od 19 VI 1889 do 10 III 1891.

56 „Hawacelet” 1890, nr 27, s. 8.

57 JRI - Poland: Przemyśl, Deaths 1790-1899, akta 285, Jakób Mojesz Amkraut - akt zgonu,
} 
Księga nosząca rozbudowany tytuł Modlitewnik wedtug rytu sefardyjskiego z komentarzem Modlitwa do Mojżesza ${ }^{58}$ ukazała się już po jego śmierci, w ostatnim kwartale 1891 roku, i opatrzona była informacją, iż została „,dostarczona do druku nakładem zmarłego Jakuba Mojżesza Amkrauta, dusza jego w raju, z Przemyśla". Jako wydawczyni książki figurowała 30-letnia wdowa po Jakubie Mojżeszu - Etel Amkraut. Modlitewnik przeznaczony był do sprzedaży także daleko poza granicami Galicji, o czym świadczy sygnowane przez Etel ogłoszenie w jerozolimskim „Hawacelet”:

Ogłoszenie. Informuję wiernie plemiona Izraela, iż wydałam Modlitewnik Tfila le-Mosze w rycie sefardyjskim świętego i boskiego człowieka, błogosławionej pamięci rabina Mojżesza Kordowero, któremu towarzyszy modlitewnik Or ha-jaszar błogosławionej pamięci Meira Poppersa oraz Derech ha-chaim w całości, w postaci czystej i objaśnionej jak w żadnym innym modlitewniku, a także kilka innych drogich i cennych ksiąg, które nie były jeszcze drukowane. Wydrukowano nowymi literami i na jaśniejszym papierze. Cena na najlepszym papierze satynowanym trzy srebrne reńskie floreny.

Adres do wysyłki pieniędzy: Etel Amkraut, Premijs' ${ }^{\prime 59}$.

Pierwszą księgą wydaną przez Amkrautów po śmierci Jakuba Mojżesza, już bez żadnego jego udziału, był wspomniany wyżej opublikowany w roku 1892 modlitewnik przygotowany przez Ch. Knollera Daat Kdoszim, zawierający modlitwy na cały rok w rycie sefardyjskim i aszkenazyjskim. Wydawcą drukowanej przez Żupnika, Knollera i Hammerschmidta księgi był młodszy brat zmarłego Abraham Izaak Amkraut.

Urodzony w Przemyślu w październiku 1858 r. Abraham Izaak poślubił 15 VI 1898 r. starszą o rok i pochodzącą z Oleszyc Szajnę Hindę z domu Prinzenthal, wraz z którą prowadził w Przemyślu oberżę ${ }^{60} \mathrm{Z}$ nieznanych nam powodów nie kontynuował on jednak pracy wydawniczej i kierowanie księgarnią oraz wydawnictwem ponownie wzięła w swe ręce E. Amkraut, wdowa po zmarłym Jakubie. Pod jej samodzielnym kierownictwem (do roku 1902) ukazały się cztery tytuły. W roku 1895 księga Pnej arie (Oblicze lwa; druk Żupnik, Knoller i Hammerschmidt) przemyskiego dajana Arie Lejba Ganza (pierwsza połowa XIX w.), poświęcona komentarzom do słynnego dzieła Józefa Karo Szulchan aruch (Nakryty stół). Rok później modlitewnik Tfila jafa (Piękna modlitwa) zawierający modlitwy na wszystkie dni roku w rycie aszkenazyjskim (druk Żupnik, Knoller i Wolf). W roku 1898 ukazała się księga responsów Kad ha-kemach (Dzban mąki; druk Żupnik i Knoller) Dawida Salomona Eibenschütza (ur. 1755, zm. 1813), rabina Chorostkowa i Budzanowa,

[online] https://www.jri-poland.org/jriplweb.htm [dostęp 24.03.2020].

58 Sidur tefilah ke-minhag Sefarad: helek rishon ,im perush Tefilah le-Mosheh.

59 „Hawacelet” 1892, nr 38, s. 8.

${ }^{60}$ JRI - Poland: Przemyśl, Marriages 1863-1899, akta 44, Abraham Izak Amkraut i Szejndla Hinda Prinzenthal - akt ślubu, [online] https://www.jri-poland.org/jriplweb.htm [dostęp 24.03.2020]. 
a w roku 1902 modlitewnik Szirej zimra (Pieśni śpiewane) według rytu sefardyjskiego. Jednocześnie Etel nadal prowadziła księgarnię, rozszerzając stale jej asortyment i rozpoczynając drukowanie katalogu oferowanych w niej wydawnictw. Praca nad katalogiem została uwieńczona powodzeniem, gdyż w ogłoszeniach zamieszczanych w czerwcu 1899 r. w wiedeńskim tygodniku „Die Welt” informowała czytelników, iż ukazał się właśnie i jest dostępny „gratis und franco" nowy katalog dostępnej w księgarni hebrajskiej literatury, liczący około 5000 pozycji ${ }^{61}$.

Fot. 6. Dwie wersje ogłoszenia E. Amkraut.

Źródło: „Die Welt”, czerwiec 1899, nr 22-26. Zdjęcie: K.D. Majus

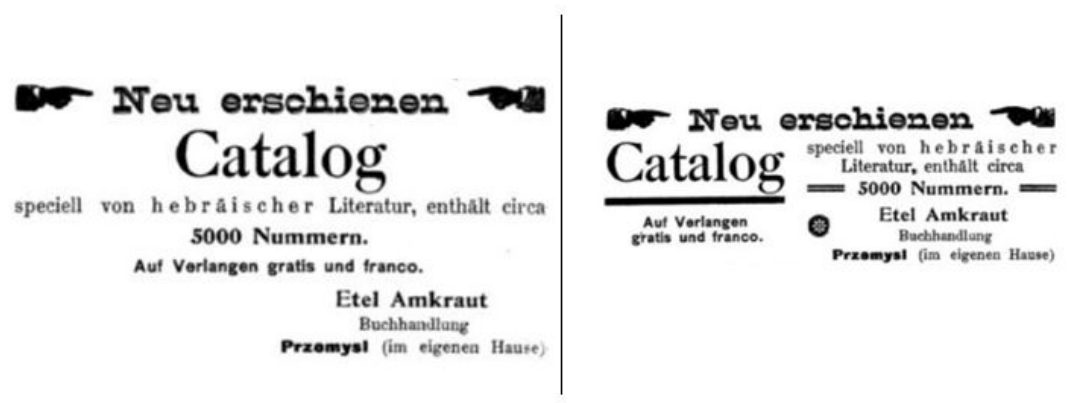

Etel kontynuowała także korespondencję ze wspomnianym już S. Buberem (aż do jego śmierci w roku 1906) i z innymi galicyjskimi wydawcami i księgarzami $^{62}$. W roku 1902 nastąpił prawdziwy przełom w dziejach wydawnictwa, gdy przystąpił do niego i objął jego rzeczywiste kierownictwo wspominany wyżej energiczny S. Freund, poślubiony niedawno mąż Etel. W roku tym ukazały się dwie księgi zatytułowane Machzor (Modlitewnik świąteczny). Pierwsza zawierała modlitwy na Nowy Rok i Sądny Dzień, a druga na trzy święta pielgrzymie (Pesach, Szawuot i Sukot). Obydwie księgi sygnowane były wspólnie przez E. Amkraut i S. Freunda. Wydania te były o tyle przełomowe, że po raz pierwszy skierowane zostały do szerokiego grona odbiorców posługujących się na co dzień językiem jidysz. Modlitwy w języku hebrajskim, uznawanym powszechnie za język ,święty”, znany tylko rabinom i niewielkiemu gronu osób świeckich wykształconych w nielicznych szkołach hebrajskich, opatrzone zostały rozbudowanymi komentarzami w języku jidysz, zwanym ówczesnym zwyczajem „hebrajskim tajcz” (tajcz - od niemieckiego deutsch). Były to jednocześnie ostatnie dwie księgi, w których występowało imię Etel jako

61 „Die Welt” 1899, nr 22 z 2.06, nr 23 z 9.06, nr 24 z 16.06, nr 25 z 23.06 i nr 26 z 30.06.

62 The National Library of Israel, The Leopold Zunz Archives, ARC 4 1222-73.1 do 73.7. Listy E. Amkraut do S. Bubera datowane od 1892 do 1905. 
współwłaścicielki wydawnictwa. We wszystkich późniejszych publikacjach, aż do roku 1924, figurowało nadal nazwisko Amkraut, gdyż S. Freund pragnął korzystać z renomy istniejącego już od ćwierćwiecza wydawnictwa, ale bez żadnego imienia. Po roku 1924 nazwisko Amkraut już więcej się nie pojawia.

Niewiele wiadomo o dalszym losie Etel, poza tym, że latem roku 1911 gościła wraz z jedną z córek w Krynicy, o czym informowała lokalna gazeta, donosząc, iż 30 maja przybyła do uzdrowiska i zatrzymała się w willi Alfredówka „Amkraut Etel, kupcowa z córką" ${ }^{63}$. Istnieje także „Karta Pamięci" na jej imię i nazwisko w Instytucie Jad Waszem, stwierdzająca, iż Etel Amkraut „sprzedawczyni książek” z Przemyśla „,zaginęła podczas Zagłady”. Karta wypełniona nie przez członka rodziny, lecz przez Komitet Męczenników Auschwitz z miasta Beer Szewa w Izraelu, nie jest jednak w pełni wiarygodna, gdyż poza powyższym stwierdzeniem nie zawiera żadnych danych osobowych prócz imienia i nazwiska ${ }^{64}$. Biorąc pod uwagę pomijanie nazwiska Amkraut w nazwie wydawnictwa od roku 1924 nie można wykluczyć, że Etel zmarła śmiercią naturalną w pierwszej połowie lat 20.

\section{Simcha Freund}

Simcha ${ }^{65}$ Freund, kontynuator wydawniczego dzieła Amkrautów, urodził się w Tyrawie Wołoskiej 16 XI $1871 \mathrm{r}^{66}{ }^{6}$ Jego ojciec nosił imię Hirsz (Cwi) ${ }^{67}$. Simcha trudnił się kupiectwem i próbował sił także w branży finansowej, zasiadając w latach 1901-1908 (jako jeden ze współzałożycieli i dyrektorów) w zarządzie przemyskiego Towarzystwa Zarobkowego i Gospodarczego „Merkur”. Celem działania towarzystwa było „za pomocą wspólnego kredytu wszystkich członków i powierzonych składek dostarczyć jego członkom na pomierny procent pieniędzy potrzebnych im do przemysłu, handlu i gospodarstwa". W roku 1910 S. Freund wchodził także w skład zarządu Towarzystwa Kredytowego

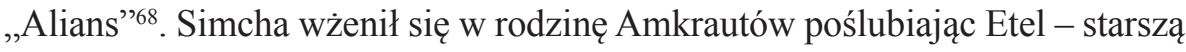
od siebie o dziewięć lat wdowę po zmarłym Jakubie Mojżeszu. Doszło do tego nie później niż w roku 1894, choć urzędowy ślub nastąpił dopiero 13 VII 1902 r. Państwo Freundowie zamieszkali w Przemyślu przy ulicy Jagiellońskiej $31^{69}$.

63 „Krynica” 1911 , nr 2 z 4.06.2011, s. 5.

64 Instytut Jad Waszem, Jerozolima, Daf ed [Karta świadectwa] E. Amkraut z 23 III 1999.

${ }^{65}$ Simcha (hebr.: radość) to dość rzadkie imię hebrajskie, spotykane dopiero od połowy średniowiecza, wymawiane w jidysz Simche i zapisywane także w formie Symcha lub Symche.

66 Israel State Archives, sygn. 6220/ M-27, Akta imigracyjne Simchy Freunda.

${ }_{67}$ Cwi to hebrajska wersja żydowskiego imienia Hirsz. Obydwa mają to samo znaczenie - jeleń.

68 A. Siciak, Dzieje książki..., s. 184; „Gazeta Lwowska” 1901, nr 146, s. 13; N. Ulmer, Statystyka ... za rok 1900, Lwów 1901, s. 56; tenże, Statystyka ... za rok 1901, Lwów 1902, s. 53; tenże, Statystyka ... za rok 1903, Lwów 1904, s. 36.

${ }_{69}$ JRI - Poland: Przemyśl, Births, akta 22, Hersz Freund/Landau - akt urodzenia, [online] 
Po urzędowym ślubie Simcha stał się współwłaścicielem mieszczących się po sąsiedzku (Jagiellońska 29) księgarni i wydawnictwa zwanego od tej pory Amkraut \& Freund (już bez imienia Etel, lecz z zachowaniem nazwy renomowanej firmy) i przejął jego faktyczne kierownictwo. Wkrótce potem podjął energiczne działania dla rozwoju wydawnictwa polegające głównie na zróżnicowaniu i rozszerzeniu charakteru wydawanych publikacji. Poza hebrajskimi księgami religijnymi wprowadził od 1907 r. także wydawnictwa świeckie w jidysz, głównie przypowieści chasydzkie, oraz szeroki repertuar jidyszowych sztuk teatralnych i operetkowych. Zmiany polegały także na przeniesieniu sporej części wydawanych publikacji do innych oficyn, zarówno w samym Przemyślu (drukarnia Schwarza i Robinsohna), jak i poza nim (krakowskie drukarnie Józefa Fischera oraz Saula Liepmana Hananii Deutschera, a po jego śmierci - jego syna Mojżesza). W latach 1910-1911 wydawnictwo współpracowało także z Natanem Nate Kronenbergiem z Biłgoraja, korzystając kilkakrotnie $\mathrm{z}$ wykonanych $\mathrm{w}$ jego drukarni matryc.

Pierwszą ze wspomnianych jidyszowych sztuk był opublikowany w roku 1907 ,obraz z życia w 4 aktach” Maksa Gebela (1877-1952) z muzyką Sigmunda Mogulesco (1858-1914), zatytułowany Tate mames cures (Kłopoty rodziców).

Od roku 1908 nastąpił prawdziwy wysyp popularnych publikacji wydawnictwa Amkraut \& Freund. Do wybuchu I wojny światowej, która z naturalnych przyczyn wstrzymała prace wydawnicze, opublikowano jeszcze około 20 dramatów, komedii i operetek takich protoplastów rodzącego się żydowskiego teatru, jak Abraham Goldfaden (ur. 1840, zm. 1908), Jakub Gordin (ur. 1853, zm. 1909), Józef Lateiner (ur. 1853, zm. 1935), Zisel Kornbluth (ur. 1872, zm. 1929), Nechemia Rakow (ur. 1866, zm. 1927), Zygmunt Feinmann (ur. 1862, zm. 1919), Meir Nachum Szajkewicz (ur. 1849, zm. 1905) czy Jakub Morgenstern (ur. 1820, zm. 1890).

W roku 1910 rozpoczęto wydawanie jidyszowych przypowieści chasydzkich kierowanych do bardziej tradycyjnych odbiorców. Pierwszą taką publikacją były Niflaot hadaszot (Nowe cuda) Jonatana Eibenschütza (ur. 1690, zm. 1764) opatrzone podtytułem „Wspaniałe znaki i cuda wielkiego, światowej sławy gaona Jonatana Eibenschütza oraz prawdziwa przypowieść Świętego z Pragi”. Rok później ukazała się w klocku wydawniczym seria ośmiu przypowieści, przy wydaniu których korzystano z biłgorajskich matryc Kronenberga. Zwyczaj wydawania takich przypowieści w klockach bądź odrębnie i sprzedawania ich także w postaci broszur bez okładek był szeroko praktykowany również w okresie międzywojennym.

Nie zaniedbywano, oczywiście, wydawania hebrajskich dzieł religijnych, wśród których brylowało opublikowane w roku 1910 słynne dwutomowe 
dzieło dynowskiego cadyka C.E. Szapiry Agra dekala (Zapłata panny młodej), drukowane także na matrycach Kronenberga.

Fot. 7. M. Gebel, Tate mames cures, muzyka S. Mogulesco, Przemyśl: Amkraut \& Freund, Druk: S.L. Deutscher [Kraków], 1907 - strona tytułowa.

Zdjęcie: K.D. Majus

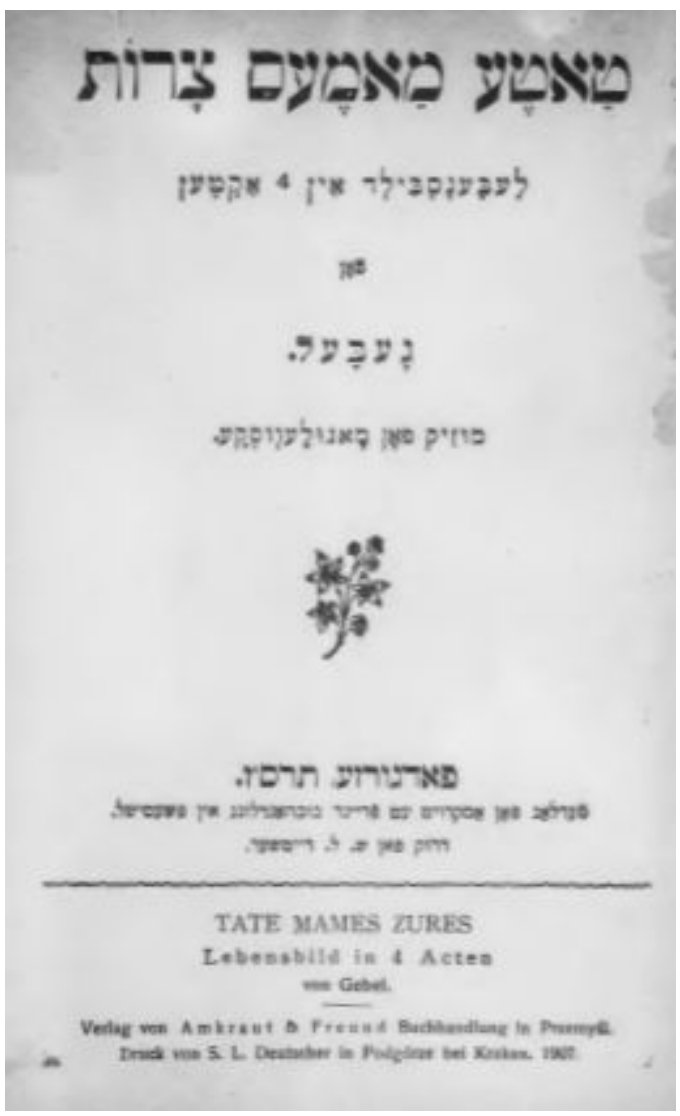

W ramach jak najszerszej dywersyfikacji oferty wydawniczej ukazało się również wydane w roku 1912 kompendium medyczne Jesodot ha-refua o gidul banim (Podstawy medycyny albo wychowywanie dzieci) Mojżesza Mahla, a prawdziwym i wielokrotnie wznawianym aż do lat 30. przebojem edytorskim był opublikowany po raz pierwszy w Przemyślu w roku 1909 dwutomowy podręcznik języka hebrajskiego Sfatenu (Nasz język) Cwi Scharfsteina (ur. 1884, zm. 1972) i Rafaela Sofermana (ur. 1879, zm. 1956), znajdujący nabywców także daleko poza Przemyślem, Galicją i Polską.

Łącznie w latach 1902-1918 firma Amkraut \& Freund sygnowała wydanie ponad 70 pozycji, co, biorąc pod uwagę przerwę spowodowaną oblężeniem 
i okupacją twierdzy Przemyśl przez armię rosyjską, oznacza publikowanie pięciu-sześciu tytułów rocznie.

W pierwszych latach II Rzeczypospolitej wydawnictwo z trudem wracało do normalnej pracy w nowej rzeczywistości po zawierusze wojennej, wydając w latach 1919-1923 zaledwie kilka drobniejszych pozycji, głównie wznowień z okresu przedwojennego. Taka kryzysowa sytuacja trwała aż do roku 1924, kiedy z nazwy firmy zniknęło nazwisko Amkraut i od tej pory wszystkie publikacje sygnowane były imieniem i nazwiskiem samego S. Freunda. Przyczyna usunięcia nazwiska Amkraut nie jest jasna. Nie wiadomo, czy Etel zmarła w tym czasie, czy wycofała się tylko z pracy wydawniczej z przyczyn zdrowotnych lub innych, czy też może drogi życiowe i zawodowe Etel i Simchy rozeszły się z bardziej prozaicznych powodów. Kwestia ta wymaga dalszych badań.

Po zmianie nazwy firmy następuje prawdziwa rewolucja. S. Freund nawiązuje współpracę ze znanym żydowskim dziennikarzem i publicystą z Austrii, będącym jednocześnie niezwykle płodnym twórcą opowieści współczesnych i historycznych, Jonasem Kreppelem (ur. 1874, zm. 1940). Jego dzieła stają się niemal wizytówką wydawnictwa. W samym tylko roku 1924 ukazuje się 31 tytułów tego autora, w roku 1925 - dziewięć tytułów, w roku 1927 - 30 tytułów, w roku 1928 - osiem tytułów i w roku 1930 - cztery tytuły. Tylko niewielka ich część to wznowienia wcześniejszych edycji. Wyróżnia się wśród nich seria ponad 20 opowiadań z okresu Wielkiej Wojny, ale nie brak również opowieści z czasów średniowiecznych i starożytnych.

S. Freund nie poprzestaje jednak na tym jednym autorze opowieści historycznych i współczesnych wydając także opowiadania innych żyjących ówcześnie literatów (M. Goldbaum, Sz. Grinberg, D. Chalfon). Kontynuuje również publikowanie hebrajskich ksiąg religijnych, jidyszowych przypowieści chasydzkich, różnego rodzaju modlitewników oraz podręczników do nauki hebrajskiego. Łącznie w latach 1924-1931 ukazało się pod firmą Simchy Freunda około 140 pozycji, co oznacza wydawanie 20 pozycji rocznie, jeśli pominąć rok 1926, w którym z nieznanych powodów zawiesił praktycznie działalność (opublikował zaledwie dwie książki). Nie można tu nie przypomnieć o wydaniu w końcu 1931 r. przez Freunda omawianego wyżej Pięcioksiagu Mojże$s z a$, w opracowaniu i przekładzie na język polski J. Miesesa. Edycja ta była niejako ukoronowaniem działalności wydawniczej S. Freunda, gdyż w roku 1931 kończy zajmowanie się pracą edytorską i pod jego nazwiskiem wychodzi do końca lat 30. zaledwie kilka kalendarzy i wznowień modlitewników, staraniem zapewne jego syna Józefa. Z początkiem 1933 r. Freund z synem Hirszem Cwi (ur. 13 I 1895 r., zm. 10 IV 1965 r.) oraz jego żoną Miną i ich dzieckiem, wyjeżdżają - oficjalnie jako turyści (,as travellers”) - do Izraela. Docierają tam, zapewne drogą morską z Włoch lub Rumunii, 27 II 1933 r. i zatrzymują się w Hajfie, w dzielnicy Hadar ha-Karmel, przy ulicy Josef pod numerem 5. 
Fot. 8. Fotografie Simchy (z lewej) oraz Cwi i Miny (z prawej) Freundów wykonane w latach 30-tych XX w. Zdjęcie: autor nieznany
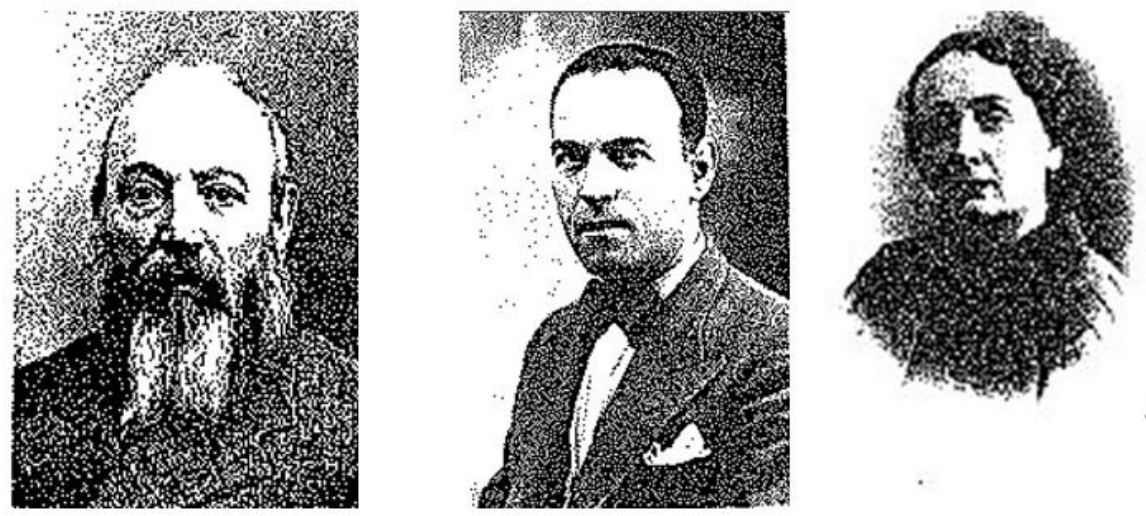

Wkrótce, bo już 10 VII 1933 r. Simcha i Cwi wraz z rodziną zmienili status turystyczny na imigrancki. Z rubryki „zawód” w oświadczeniach imigracyjnych złożonych pięć lat po przybyciu do Izraela wynika, iż S. Freund był właścicielem dwóch domów w Hajfie, a jego syn pracował jako sekretarz w hajfskim Stowarzyszeniu Właścicieli Nieruchomości. S. Freund zmarł w piątek 23 VI 1944 r. i został pochowany w Jerozolimie na cmentarzu na Górze Oliwnej. Na jego macewie widnieje napis:

\author{
Tu został pochowany \\ pan Simcha Freund błp. \\ wydawca z Przemyśla \\ syn pana Cwi błp. \\ piąte pokolenie po dostojnym \\ panu Cwi błp. \\ Kaznodziei z Dynowa ${ }^{70}$. \\ Zmarł w piątek w wigilię świętej Soboty \\ 2 Tamuz 5704 [23.06.1944] \\ Niech będzie dusza jego zawiązana \\ w woreczku żywych \\ 5631-5704 [1871-1944]
}

70 Wspomniany w inskrypcji Cwi - Kaznodzieja z Dynowa, to słynny chasydzki admor C.E. Szapira, założyciel dynastii dynowskich cadyków. 
Fot. 9. Macewa na grobie Simchy Freunda. Zdjęcie: K.D. Majus

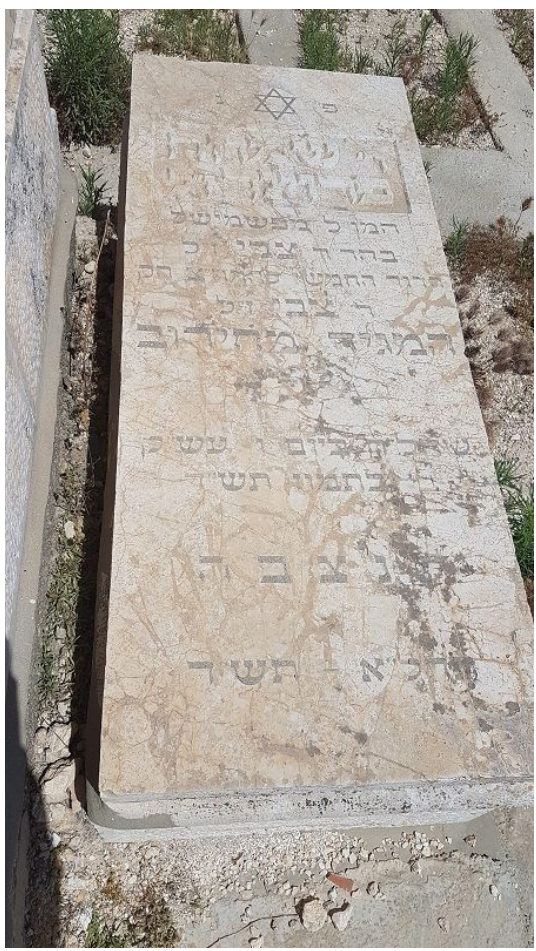

$* * *$

Poznanie dziejów przemyskich drukarzy i wydawców druków w językach hebrajskim i jidysz jest ważne dla kultury w ogóle, a dla dziejów książki w Polsce w szczególności, zwłaszcza w kontekście bogatej wielokulturowości Przemyśla już od zarania jego dziejów. Pozwala ono na szersze spojrzenie na historię regionu przemyskiego, nierozerwalnie związaną z dziejami Polski i Ukrainy, oraz na wkład zamieszkujących ten region Żydów w życie gospodarcze i kulturę obydwu tych krajów. Symbolem tej wielokulturowości niech będzie wspomniane w artykule hebrajskie tłumaczenie Ojca zadzumionych Słowackiego drukowane w oficynie kapituły biskupstwa greckokatolickiego... 


\section{Bibliografia}

Archiwalia:

Archiwum Państwowe w Przemyślu, sygn. 56/397/0/0/3829. Klepsydra Klemensa Robinsohna właściciela drukarni, zmarłego 9 V 1933 r.

Instytut Jad Waszem, Jerozolima, Daf ed [Karta świadectwa] E. Amkraut z 23 III 1999.

Israel State Archives, sygn. 6220/ M-27. Akta imigracyjne Simchy Freunda.

The National Library of Israel, The Leopold Zunz Archives:

ARC 4 1222-73.1 do 73.7. Listy Etel Amkraut do Salomona Bubera datowane od 1892 do 1905 ,

ARC 4 1222-72.1 do 72.6 oraz 73.1 do 73.7. Listy Jakuba Mojżesza Amkrauta do Salomona Bubera datowane od 19 VI 1889 do 10 III 1891.

Portale internetowe:

Chewra Kadisha Hajfa [Bractwo Pogrzebowe Hajfa] (http://kdh.org.il).

Gesher Galicia, The Bridge to Galicia (https://www.geshergalicia.org).

JewishGen, The Global Home for Jewish Genealogy (https://www.jewishgen.org) .

Jewish Record Indexing - Poland (https://www.jri-poland.org).

Opracowania:

Aszkenazy M.Ch., Sefer Malkiel, Przemyśl 1871.

Attar Ch. ibn, Riszon le-Cijjon, Przemyśl 1871.

Auerbach I.M., Imrej bina, Przemyśl 1885.

Bednarski Sz., Materyaty do historyi o drukarniach w Polsce, a mianowicie o drukarniach lwowskich i prowincyonalnych, Lwów 1888.

Ber I.D., Kahal chasidim he-chadasz, Przemyśl 1902.

Ber I.D., Mewaser cedek, Przemyśl 1870.

Bedarsi J., Bchinat olam, Przemyśl 1872.

Birkat ha-mazon, Lemberg 1865.

Ehrenkranz Zbarażer B.W., Makal noam, Lemberg 1868.

Eibenschütz D.S., Kad ha-kemach, Przemyśl 1898.

Eibenschütz J., Niflaot hadaszot, Przemyśl 1910.

Friedberg Ch.B., Toldot ha-dfus ha-iwri be-Polania mi-reszit hiwasdo be-sznat 694 we-hitpatchuto ad zmanenu, wyd. 2, Tel Awiw 1950.

Friedman I., Irin kdiszin, Przemyśl ok. 1930.

Ganz A.L., Pnej arie, Przemyśl 1895.

Gebel M., Tate mames cures, muzyka S. Mogulesco, Przemyśl-Kraków 1907.

Hagada szel Pesach, Przemyśl 1910, 1925.

Handbuch des Statthalterei-Gebiets in Galizien für das Jahr 1865, Lemberg 1865.

Jafec J., Or ha-chaim, Przemyśl 1873, 1883. 
Jagusztyn A., Drukarstwo regionu przemyskiego w okresie II Rzeczypospolitej, „Przemyskie Zapiski Historyczne" 1980, t. 2, s. 133-150.

Jakimyszyn A., Żydowska książka religijna drukowana we Lwowie w drugiej połowie XIX i na poczatku XX stulecia, [w:] Lwów. Miasto - Społeczeństwo - Kultura. T. 9: Życie codzienne miasta, red. K. Karolczak i Ł.T. Sroka, Kraków 2014, s. 157-177.

Joles J.C., Mlo ha-roim, Przemyśl 1884.

Kahane A., Masot al sofrim u-anszej szem, Przemyśl 1934.

Kahane A., Sefer ha-bdichot we-ha-halacot, Przemyśl 1935.

Kahane A., Szirej gola we-geula, Przemyśl 1933.

Knoller Ch., Ben cheled, Przemyśl 1900.

Knoller Ch., Daat kdoszim, Przemyśl 1892.

Knoller Ch., Dwar jom be-jomo, Przemyśl 1907, 1933.

Knoller Ch., Kwod chachamim, Przemyśl 1898.

Knoller Ch., Megilat Eicha, Przemyśl 1893.

Knoller Ch., Megilat Ester, Przemyśl 1894.

Knoller Ch., Megilat Kohelet, Przemyśl 1891, 1896.

Knoller Ch., Megilat Rut, Przemyśl 1893.

Knoller Ch., Megilat Szir ha-Szirim, Przemyśl 1890, 1894.

Knoller Ch., Midrasz Raba al ha-Tora, Przemyśl 1932, 1936.

Knoller Ch., Perusz al Midrasz Raba, Przemyśl 1936.

Knoller Ch., Pri chaim, Przemyśl 1883, 1936.

Kordowero M., Sidur tefilah ke-minhag Sefarad: helek rishon ,im perush Tefilah le-Mosheh, Przemyśl 1891.

Machzor [modlitwy na Nowy Rok i Sądny Dzień], Przemyśl 1902.

Machzor [modlitwy na na trzy święta pielgrzymie: Pesach, Szawuot i Sukot], Przemyśl 1902.

Mahl M., Jesodot ha-refua o gidul banim, Przemyśl 1912.

Meisels J.Ch.L., Tiferet Josef, Przemyśl 1869.

Michelson A.C.S.B., Dower szalom, Przemyśl 1930.

Mikraot Gdolot, Przemyśl 1899, 1903.

[Nekrolog Chaima Knollera], „Ognisko” 1927, nr 9, s. 3.

Neumüntz M.E., Halacha le-Mosze, Przemyśl 1874.

Nitzani D., Batej dfus iwriim be-Pszemiszl, [w:] Sefer Pszemiszl (Przemyśl Memorial Book), red. A. Menczer, Tel Awiw 1964, s. 89.

Ohalej Szem, Przemyśl 1929.

Pięcioksiąg Mojżesza. Ks. 1-5, w języku hebrajskim z przekł. pol. Józefa Miesesa, Przemyśl 1931.

Raszi, Likutej ha-pardes, Lemberg 1866.

Ricchi R.E.Ch., Maase choszew, Przemyśl 1883.

Rosenstein N., Lurie R., The Lurie Legacy. The House of Davidic Royal Descent, Bergenfield (N.J.) 2004. 
Scharfstein C., Soferman R., Sfatenu, Przemyśl 1909.

Siciak A., Druki przemyskie 1754-1939. Bibliografia publikacji polskich, niemieckich, węgierskich, francuskich oraz żydowskich i ukraińskich wydanych alfabetem łacińskim, Przemyśl 2002.

Siciak A., Dzieje książki w Przemyślu w okresie autonomii Galicji (1867-1914), Przemyśl 2012.

Sleziński J., Neu verbesserter Wegweiser der kön. Hauptstadt Lemberg oder Uebersicht sämmtlicher Herrn Hauseigenthümer mit Angabe der Hausnummern, Gassen und Pfarreien, Lemberg 1863.

Słowacki J., Awi ha-nigafim be-midbar El-Arisz, tłum. M.D. Geszwind, Przemyśl 1883.

Szapira C.E., Agra dekala, Przemyśl 1910.

Szapira C.E., Klej ha-roim, Przemyśl 1883.

Szematyzm królestwa Galicyi i Lodomeryi z wielkim księstwem krakowskiem na rok 1872, Lwów 1872.

Szirej tiferet, Przemyśl 1871.

Szirej zimra, Przemyśl 1902.

Szpital żydowski w Przemyślu (Księga jubileuszowa) 1924-1934, Przemyśl 1935.

Tewel D., Nefesz Dawid, Przemyśl 1878.

Tfila jafa, Przemyśl 1896.

Trau H., Ha-klojz ha-gadol we-klojzlech, [w:] Sefer Pszemiszl (Przemyśl Memorial Book), red. A. Menczer, Tel Awiw 1964, s. 126.

Ulmer N., Statystyka stowarzyszeń zarobkowych i gospodarczych w Galicyi $z$ W. Księstwem Krakowskiem za rok 1894... 1912, Lwów 1895-1913.

Vital Ch., Limudej acilut, Lwów 1850.

Warszawiak J., Słowacki w języku Biblii, „Nasz Przegląd” 1939, nr 190, s. 19.

Weisel N.H., Szirej tiferet. Przemyśl 1870.

Wunder M., Meorej Galicja. Enciklopedia le-chachmej Galicja (Meorei Galicia. Encyclopedia of Galician Rabbis and Scholars). T. 1-6, Jeruszalaim 1978-2005. 